Illinois State University

ISU ReD: Research and eData

Theses and Dissertations

6-24-2020

\title{
Yay Or Nay? A Media Analysis Of How Deception Is Utilized As A Leadership Tactic In The Television Show Sons Of Anarchy
}

Bruce T. Lanigan

Illinois State University, BruceLanigan28@gmail.com

Follow this and additional works at: https://ir.library.illinoisstate.edu/etd

Part of the Communication Commons

\section{Recommended Citation}

Lanigan, Bruce T., "Yay Or Nay? A Media Analysis Of How Deception Is Utilized As A Leadership Tactic In The Television Show Sons Of Anarchy" (2020). Theses and Dissertations. 1295.

https://ir.library.illinoisstate.edu/etd/1295

This Thesis is brought to you for free and open access by ISU ReD: Research and eData. It has been accepted for inclusion in Theses and Dissertations by an authorized administrator of ISU ReD: Research and eData. For more information, please contact ISUReD@ilstu.edu. 


\title{
YAY OR NAY? A MEDIA ANALYSIS OF HOW DECEPTION IS UTILIZED AS A LEADERSHIP TACTIC IN THE TELEVISION SHOW SONS OF ANARCHY
}

\author{
Bruce T. Lanigan
}

101 Pages

Individuals see deception on a daily basis. One of the places most people endure deception is in the workplace. This thesis analyzes how the television show Sons of Anarchy portrays deception by leaders in the workplace. Various story arcs portraying deceptive actions are analyzed through the lenses of leader-member exchange theory and interpersonal deception theory. This thesis encourages scholars to consider studying deception in terms of direct and indirect deception. Additionally, the findings reveal that Sons of Anarchy portrays that transformationalleaders utilize deception more effectively while transactional leaders use deceptive measures more frequently.

KEYWORDS: leadership; transformational; transactional; deception; power; Sons of Anarchy 
YAY OR NAY? A MEDIA ANALYSIS OF HOW DECEPTION IS UTILIZED AS A LEADERSHIP TACTIC IN THE TELEVISION SHOW SONS OF ANARCHY

BRUCE T. LANIGAN

A Thesis Submitted in Partial Fulfillment of the Requirements for the Degree of

MASTER OF SCIENCE

School of Communication

ILLINOIS STATE UNIVERSITY 
(C) 2020 Bruce T. Lanigan 
YAY OR NAY? A MEDIA ANALYSIS OF HOW DECEPTION IS UTILIZED AS A LEADERSHIP TACTIC IN THE TELEVISION SHOW SONS OF ANARCHY

BRUCE T. LANIGAN

COMMITTEE MEMBERS:

Phillip Chidester, Chair

Aimee Miller-Ott

Stephen Hunt 


\section{ACKNOWLEDGMENTS}

Shanna Carlson has put up with me ever since I took COM 210 with her - she was also the first person I told I was applying to graduate school. Shanna, I cannot thank you enough for how much you have done for me. Whether it be proofreading my writing, brainstorming ideas for the rhetoric papers, or just conversing in your office about the Masked Singer or Love is Blind - I would not be here without you. One piece of advice you gave me was to take a course by Dr. Zompetti. Hey Zomp, your writing tips will forever be engrained with me. Although I know you will find typos in this, your courses have immensely enhanced my work ethic, and rhetoric will always be a reminder for me to keep pushing forward.

“Knock-knock, it's just me" will be a saying I will miss hearing. Patty, you have done so much for me (and the entire SOC) throughout my time at ISU, and I wanted to thank you for everything. My time as your assistant for the speech lab, a transformers mentor, and Operation Santa have been experiences I will never forget. Thank you again!

Dr. Miller-Ott and Dr. Hunt, thank you for being a part of my committee. I appreciate all the feedback you have both provided and made this project the best it could be. To my family and my friends, thank you for being there to listen if I needed ideas or if I wanted to complain could not have done this without any of you.

When I first met Phil in COM 372, I never imagined how much we would do together. From traveling to Fortaleza, numerous courses together, the countless hours spent in your office, and being my mentor throughout graduate school; it has been a pleasure. Once this is all said and done, we need to make some Coxinhas! These past three years have flown by, obrigado por tudo, Phil!

B.T.L. 


\section{CONTENTS}

Page

ACKNOWLEDGMENTS

CHAPTER I: INTRODUCTION 1

Purpose of the Study 3

What is Sons of Anarchy? 3

$\begin{array}{ll}\text { Deception in Communication } & 7\end{array}$

TV Portrayals of Deception $\quad 8$

$\begin{array}{ll}\text { Traits of Leadership } & 9\end{array}$

Previous Studies on Sons of Anarchy 11

$\begin{array}{ll}\text { Method } & 14\end{array}$

Preview of Thesis Chapters 15

CHAPTER II: LITERATURE REVIEW 17

$\begin{array}{ll}\text { Deception } & 17\end{array}$

$\begin{array}{ll}\text { Motives } & 18\end{array}$

$\begin{array}{ll}\text { Detection } & 18\end{array}$

$\begin{array}{ll}\text { Domains } & 21\end{array}$

$\begin{array}{ll}\text { Leadership } & 23\end{array}$

$\begin{array}{ll}\text { Transformational Leadership } & 24\end{array}$

$\begin{array}{ll}\text { Transactional Leadership } & 25\end{array}$

Transformational \& Transactional 26

$\begin{array}{ll}\text { Power } & 27\end{array}$

$\begin{array}{ll}\text { Legitimate Power } & 28\end{array}$ 
Reward Power

Coercive Power

Informational Power

Deception and Power

Deception and Leadership

Media Representations of Leadership and Deception

Previous Research on Sons of Anarchy

Conclusion

CHAPTER III: METHOD

Synopsis of Sons of Anarchy

Data Collection

Theoretical Background

Leader-Member Exchange Theory

Interpersonal Deception Theory

Previewing the Story Arcs

Deception for the Clubs Sake

Direct Deception

Indirect Deception

Deception for Self-gain

Direct Deception

Indirect Deception

Deception for both the Clubs Sake and Self-gain 
$\begin{array}{ll}\text { Direct Deception } & 65\end{array}$

$\begin{array}{ll}\text { Indirect Deception } & 66\end{array}$

$\begin{array}{ll}\text { Analysis of Discussion and Findings } & 69\end{array}$

Discussion of Leadership Styles in SAMCRO 70

$\begin{array}{ll}\text { Subordinates’ Reactions to Leadership } & 74\end{array}$

$\begin{array}{ll}\text { Potential Messages to Viewers } & 79\end{array}$

$\begin{array}{ll}\text { Conclusion } & 82\end{array}$

$\begin{array}{ll}\text { CHAPTER V: DISCUSSION } & 83\end{array}$

Directions for Future Research $\quad 84$

$\begin{array}{ll}\text { Story Arc Limitations } & 85\end{array}$

Discussion of Direct Deception Versus Indirect Deception 86

Discussion of Relationships in the Workplace 86

Discussion of Transformational and Transactional Leadership $\quad 87$

$\begin{array}{lr}\text { Conclusion } & 89\end{array}$

$\begin{array}{ll}\text { REFERENCES } & 91\end{array}$ 


\section{CHAPTER I: INTRODUCTION}

Malone (2003) and Levine (2014) explain that deception is a premeditated attempt to misinform others. Usually, deception is carefully planned out, but in some circumstances, such as lying, can be put together in the heat of the moment. People encounter deception daily, whether it be themselves being the deceiver, they are the ones being deceived, or simply witnessing deception as a bystander or in the media. Lindsay, Dunbar, and Russell (2008) found that $45 \%$ of employees stated they used deception in their workplace. The workplace is just one place people can encounter deception throughout their day, but more importantly is figuring out the meaning behind the use of deception and if some are better at it than others.

The idea for this study stems from my experiences while I was working for Jersey Mike's. In the beginning, the job was great -- it was everything I had hoped for. As I made my way up the hierarchy, I noticed how politics was an essential part of succeeding -- it was almost like a game. As time went on, I learned how to play the game -- and I learned how to play the game well. When I took over as the General Manager at Jersey Mike's, I found myself using deception with my employees. I would alter the way I conversed with individual employees to receive what I wanted. Honestly, I thought I was justified in doing this because of how much I was also on the receiving end of it from my supervisors. My personal experience using deception in the workplace has allowed me to see how others use deception and how it could be used within personal relationships too. Moreover, my experiences at Jersey Mike's showed me how deception could be used in the workplace - this has made me curious to know how others might learn these techniques too.

My situation had me conflicted because I hated being on the receiving end of the deception. I never knew I was being deceived until it was too late - and once I found out, it 
would put a strain on the general manager's relationship with me. After I knew my manager was deceitful, I would make sure I conversed with him cautiously and make sure I was not the first employee to volunteer to work extra. But then I also recognized how using deception made the managerial position easier. As a leader, it is difficult to utilize deception effectively because not only are you lying to the employees, but the leader needs to hide the fact they are lying too. This is where a web of lies is created due to the frequent use of deception. This is where interpersonal deception theory comes into place. Interpersonal deception theory is all about how deception is utilized in interpersonal relationships - whether those relationships are personal or professional. The theory argues that people are not as good at detecting deception as they think they are. Deception as a concept is unique because it assists us in seeing the overlap between the interpersonal and organizational relationships. Therefore, interpersonal deception theory will serve as one of the theoretical lenses later in this thesis.

In addition to the workplace, others may learn how to use deception in school, in literature, or even on television. People can learn how to use deception from these outlets as a result of parasocial relationships. Aytulun and Sunal (2020) describe parasocial relationships as a one-sided relationship where an individual feels connected to a fictional character in media whether it be in literature, a television show, or a movie. If viewers identify strongly with one of the characters in a show, there are chances they start displaying similar qualities to said character. This can go both ways meaning if a person sees a character they like employing deception and it is turns out to be successful, there may be individuals who decide to utilize deception in a similar manner. On the other hand, if there is a character they dislike and see how deception could be used in a negative manner, they may learn how to stay away from engaging in similar behaviors. 


\section{Purpose of the Study}

The purpose of this study is to examine the portrayal of deception and leadership in Sons of Anarchy. Specifically, this study will look at how relationships, both professional and personal, will affect how deception is used. This is important because once personal relationships start to intertwine with professional relationships, it could start to bring negative consequences to the organization. The characters which will be analyzed within Sons of Anarchy are Clay and Jax. These characters are both leaders but have different motives for their actions. Moreover, Clay is the stepfather to Jax, so, in addition to learning about their workplace relationships, there will be a look into their personal relationship as well. These two characters have a close relationship, and this may be a cause of why the tensions between both leaders arise at times. I want to discover how deception works within an organization, and I believe some of the deceptive practices by both characters are done in spite of one another since their relationship is close. This would allow me not only to see how deception affects professional relationships but additionally, personal relationships. Therefore, I think it is essential to examine both professional and personal relationships with this study and see how it affects deception as a leadership strategy.

\section{What is Sons of Anarchy?}

Sons of Anarchy was a television show on FX from 2009 to 2015 for seven seasons. According to Littleton (2014), the show's series finale brought in 9.26 million viewers - this broke the show's own record for having the most-watched season on FX. The article also quoted FX's CEO, John Landgraf, stating, "It's a rare and remarkable accomplishment for a television show to generate its - and our channel's - highest ratings in its final season" (p. 5). As for the show's critical response, it holds up at $88 \%$ on Rotten Tomatoes, an 8.6 rating on IMDb and 
TV.com - which are all respected media critic sites. Due to the popularity and success of the show, at one point in time, streaming services Netflix and Hulu had this show available on their platform. This show reached nearly ten million people while it was airing on cable. Since 2009, Sons of Anarchy has impacted millions of people. Now that the show is available via streaming services, it will continue to influence others for many years to come.

The show focuses on Sons of Anarchy Motorcycle Club Redwood Originals (SAMCRO). A "motorcycle club" is a group of adult men, some younger, some older, who share the connection of being a motorcycle enthusiast. The Mongols and Hells Angels are real-life motorcycle clubs. Both clubs are well-known to authorities and have reputations for partaking in violent and illegal acts. Any group of this nature is frightening to the local community. As a result, if there is any influence over local law enforcement officials, they can get away with quite a bit of illegal operations.

The show is set in the fictional town of Charming, California. Within Charming, SAMCRO is seen as a political force - sometimes having more authority than the local police department. Although most residents would be opposed to letting an outlaw group run their town, SAMCRO takes care of their own. It is known that members of the club do not allow others to deal drugs or let violent incidents take place within Charming's borders. The club's relationship with law enforcement allows them to get away with a lot, which keeps the townspeople a bit afraid of them. Still, because they aim to keep strangers from victimizing the locals, the people of Charming are pretty accepting of the club.

The Sons of Anarchy are an international motorcycle club comprised of various charters located around the world. A charter is also known as a branch. Although Clay served as president for a long time, he was not the founder of the club. SAMCRO was founded by Piney Winston 
and John Teller, Jax's biological father. Other recurring SAMCRO members appearing throughout the series are Chibs Telford, Bobby Munson, Tig Trager, Harry “Opie” Winston, Carlos "Juice" Oritz, Happy Lowman, and the prospects. A prospect is an individual who is trying to get patched (initiated) into the club but is on a trial run with the club - this is a crucial period where they need to prove themselves to the rest of the club members.

In addition to the SAMCRO members, various supporting characters are vital to the television story. Gemma Teller is Jax's mother and Clay's “old lady." An old lady is another name for a wife or girlfriend of a club member. Gemma serves as the matriarch and has a pivotal role that contributes to the motorcycle club. Like Gemma, Tara Knowles is Jax's old lady and serves as SAMCRO's doctor whenever they need medical assistance. Lastly, it is common to see law enforcement officials clash with the Sons of Anarchy. It is known throughout the community that police officers Wayne Unser and David Hale have worked alongside SAMCRO. Although they do not like admitting they turn a blind eye to some of the activity SAMCRO engages in, they have more of an old-school mentality of as long as it is for the good of Charming, then it is justified. In addition to Unser and Hale, SAMCRO deals with other law enforcement agencies throughout the series. The other officials are not from Charming - therefore, they keep a closer eye on the club because instead of seeing the Sons of Anarchy as vigilantes, they see them as criminals.

Like the Sons of Anarchy, there are other gangs present throughout the series. The Mayans are a Mexican motorcycle club located in California. The Mayans are a familiar acquaintance of SAMCRO seen throughout all seven seasons. The One-Niners (better known as the 9'ers) are an African American based street gang based out of California that has frequent interactions with both SAMCRO and the Mayans. Although both the Mayans and the One- 
Niners are enemies at points throughout the show, SAMCRO's interactions with each gang make up significant storylines throughout the series.

There are scenes within the show where law enforcement officers question SAMCRO members about their illegal activities. Usually, the responses are along the lines of "we are just a group of mechanics who are motorcycle enthusiasts." Even though that may be true, they are trying to deceive the officers away from the fact that they are also part of a criminal organization. The Sons of Anarchy engage in illegal weapon sales, and they provide protection to local businesses. As the series progresses, SAMCRO starts to draw more attention to its criminal operations. Therefore, they start managing a porn studio and escort business to show they are a legitimate organization, but the illegal operations are where a majority of their capital comes in. SAMCRO supplies both the Mayans and One-Niners with weapons. Therefore, they try to keep the relationships between the clubs neutral. Even though the One-Niners have a president of their own, they still answer to someone. Damon Pope was one of the most dangerous gangsters in California who oversaw various criminal organizations such as the One-Niners. Pope makes his presence known to SAMCRO after Tig accidentally kills his daughter. After a chain of events takes place, Pope is killed, and his successor is August Marks. Marks is more ruthless and dangerous than Pope - this would eventually turn into a massive problem for SAMCRO.

If a reader were not aware of the background information of this show, then they would not comprehend the complexity of the overall moving variables. For example, SAMCRO has affiliations with The Mayans and the One-Niners. Despite the fact all three organizations have their differences with one another, the leaders must take control and make sure there is a line of respect between the clubs for business to continue operating. Furthermore, SAMCRO needs to protect the city of Charming and keep good faith with the local law enforcement officials, who 
are usually investigating them. The club members must also work to maintain their personal lives and relationships. All of this is a significant responsibility that falls on the leader. Therefore, it is important to examine how Clay and Jax operate within their leadership position because the legacy of the club depends on them, and the utilization of deception could ultimately be the deciding factor.

\section{Deception in Communication}

Deceptive practices can be used in many contexts. Over the past six years, I have been on both sides of deception. While I was a typical team member at Jersey Mike's I would fall victim to deceptive practices regularly. On the other hand, once I obtained a leadership position, I found myself using deception too. Deception is defined as "the conscious alteration of information a person believes to be true to significantly change another's perceptions from what the deceiver thought they would be without alteration" (Wang, 2004, p. 112). Deception is a skill one may possess, and it can be used for both good and bad. When individuals engage in deception they are trying to gain the upper hand in the situation. These individuals might want something from that other person, they are trying to hurt someone, or maybe they are trying to save face. Whether people are aware of it or not, deception is seen in many facets of life, one of them being in the workplace.

Using deception in the workplace might not be the most ethical thing to do, but as someone who stood in the leadership position, I understand why it is used. Dunleavy (2010) looks at the responses to deception being used in the workplace - specifically looking at perceptions of credibility, power, and trustworthiness. The researcher provided participants with differing scenarios (honest, withholding deceptive, distortion deceptive). As a result of reading the scripts, the participants said one who is honest upfront has a higher quality of character, 
trustworthiness, power, and credibility - all characteristics a leader must possess. This study would be a good example for when I discuss how SAMCRO felt toward Clay at the end of his tenure as president and the shift toward Jax, who was more honest with the other members. Deception is usually associated with negative implications because it is when one alters information to gain something they want. Pienaar (2009) examined leadership ineffectiveness and introduced a new element that other researchers were not looking at - deception. The researcher said that deception could be regarded as a leading factor that contributes to leadership ineffectiveness. Throughout Sons of Anarchy, there are times when deceptive practices have been used, and, in some instances, there was backlash toward the leader.

This study would help further explain what caused that backlash and provide a better understanding to not only why deception contributes to leadership ineffectiveness, but also explain why leaders choose to engage in deceptive practices rather than be honest from the beginning.

\section{TV Portrayals of Deception}

There are various motives for why one would use deceptive tactics. Mazur (2003) analyzed deceptive practices seen within television families. The results of the study showed that within each family, the father figure was the one who lied most frequently. Additionally, the researcher found most lies went undetected, and the most common reason for lying was to spare others' feelings. Looking at this article through the lens of the family communication patterns theory will assist in analyzing why these characters engage in deception and seeing if the results are worth it.

Mad Men is another television show that reached mainstream popularity. Prince (2011) analyzes how deception is used from the standpoint of motivation, appeal, and consequences for 
relationships and the self. This article will be useful for my study because I will be able to compare the similarities and differences seen between both shows. In Sons of Anarchy, the show revolves around a group of outlaw bikers -- Mad Men concentrates on people who work within an advertising agency. This would be an interesting comparison because one show is about a criminal organization, and the other is about a legitimate business agency. It would be compelling to see if there were any similarities or differences in the motives behind the use of deception since both shows have many different contexts.

\section{Traits of Leadership}

To adequately analyze the relationship between leadership and deception in the television show Sons of Anarchy, it is important to understand some general traits and characteristics of leadership. A leader is vital to the success of an organization - without one, an organization is likely to deteriorate. Leadership can be defined as

One or more people who selects, equips, trains, and influences one or more follower(s) who have diverse gifts, abilities, and skills and focuses the follower(s) to the organization's mission and objectives causing the follower(s) to willingly and enthusiastically expend spiritual, emotional, and physical energy in a concerted coordinated effort to achieve the organizational mission and objectives. (Winston, 2016, p. 7)

Winston argues that leaders must be able to identify with their subordinates and have their respect. If a leader is not able to motivate followers, then the daily operations will start to unbind, and the organization can disintegrate. Sungu (2019) and Zeinab (2019) both published articles analyzing organizational commitment and job performance. The results from Sungu (2019) showed that employees had better job performance and higher occupational commitment when 
there was a transformational leadership approach displayed by their supervisors. As Jax is emerging as the president of SAMCRO, he portrays himself as a transformational leader, and the other members stand behind him in his actions. These studies will help me understand why followers do better under this type of leadership versus different leadership styles. Additionally, this information will assist in recognizing which leadership style might be more susceptible to using direct deception as a leadership strategy.

Transactional leadership differs from transformational leadership. Polic (2019) analyzed the proactivity of employees during crisis events based on which leadership style is displayed. This article will be integral to my study for several reasons. First, this article gives a better understanding of what transactional leadership is and how it is different from transformational leadership. Furthermore, SAMCRO finds itself in crisis situations frequently. This article will be an essential tool to examine how subordinates react to their superiors based on which leadership style is present. It will be interesting to see if the results of the study match the character's actions in the show since Sons of Anarchy portrays the club's members acting differently under Jax (who represents more of a transformational leadership style) and Clay (who displays more of a transactional leadership style).

During my years as an undergraduate student in organizational communication, I noticed most information presented to the class would always be applied back to typical examples of leadership roles within the business sector. SAMCRO is not your average business. Yes, during the day, the members work as legitimate mechanics, but it is all a front for a more significant operation - the criminal enterprise. A gang operates as an organization - they have a hierarchy of leadership and business operations; just as non-criminal enterprises do. 
Researchers have studied leadership in the past. However, the research into leadership in street gangs is incomplete. Densley (2012) looks at how leadership is portrayed in London street gangs. Additionally, the researcher examines the overall structure of the gang life, such as their public perception, the hierarchal structure within the gang, the rules and responsibilities that all members must follow, and the communication with the surrounding communities. This study will help shed light on the business aspect of a gang because although gangs are criminal organizations, they function as any business would. Moreover, as seen in SAMCRO, Jax and Clay both engaged in deceptive practices, whether it be for the benefit of the club or more of a personal gain. Since the show depicts which use of deception is most beneficial, this article will be helpful to my study.

\section{Previous Studies on Sons of Anarchy}

Sons of Anarchy has been the focus of research. studies before but not solely focusing on how leaders utilize deception. Most of this previous research deals with representations of masculinity, and the show's similarities to Shakespeare's Hamlet. Wayne (2014) analyzes white masculinities and moral ambiguity through three television series, one being Sons of Anarchy. This article discusses racism and how two characters within the show, the antihero protagonist (Jax) and the antagonist (Clay) display racist characteristics. This article will help to frame my study because it shows how storylines can be mined to reveal the characters' core qualities. Analyzing storylines in the text will allow me to explain how Clay and Jax are portrayed while using deception as leaders in various ways to achieve both personal and organizational ends of their own and of the club.

In another article looking at the show in terms of masculinity, Wood (2016) defined hypermasculinity as "an exaggerated set of cultural norms and behaviors usually associated with 
males, as a strategy for creating not just legitimacy, but also a scenario of power itself”' (p. 330). The entire premise of being a member of SAMCRO is brotherhood. Furthermore, masculinity is often displayed as an aggressive response to threats, and there are connections with those who experience these incidents together. The characters on Sons of Anarchy are frequently characterized as having these kinds of experiences. Cox (2016) inspected the hypermasculinity that is present throughout SAMCRO. Throughout the show, Jax is trying to reign as president of SAMCRO. To do that, he needs to prove himself among his fellow brothers. Displaying hypermasculinity is a way for this to help his case because it would show he is ready to emerge as the leader of SAMCRO.

Wood (2016) further explains the masculine control over oneself and others. For an individual to take control over oneself and their subordinates is a masculine trait that a leader must possess. On Sons of Anarchy, a male's control and dominance, first and foremost, is marked by his ability to have control over himself. While the series places men at the center of the action and thereby in control of most situations, this is mitigated by action that is often prompted by the motorcycle club's need for damage control and attempts to gain "leverage" over others. In other words, motorcycle club members often act in response to others' actions. (Cox, 2016, p. 822) Cox does not explicitly link masculine characteristics to leadership, but my study will point out how leaders need to possess masculine characteristics. This article will help me display how important it is that Jax emerges as a hypermasculine leader because his peers will support him. If he ever wanted to use deception against any of his own, they would have to believe he is the top-dog because if not, they would not buy into his deceptive tactics. In this context, the leader must be hypermasculine. 
Furthermore, like Cox, Nijjar (2018) analyzed mutated masculinities of protagonists seen in television dramas such as Sons of Anarchy. The researcher examined how one who holds a "new lad" (a man that holds traditional male attitudes) approach alters to more of a "new man" (a man that does not hold the traditional male values) approach and how it affects their leadership capabilities. To carry out this study, the researcher conducted a textual analysis to examine specific images of male characters. After doing a textual analysis, Nijjar engaged in discursive analysis to analyze any latent discourses that are seen throughout the materiality of Jax's body Nijjar goes on to further explain that this is a way to communicate distinct interpretations about hegemonic masculinity. Lastly, Nijjar utilized a socio-cultural analysis to look at the production of the show and analyze the practices of masculinity within it. This article will help in my study by examining what it looks like to be masculine today. The article discusses how a "new man" does not abide by the traditional male views. At the beginning of the show, Jax can be seen as a "new lad." As the show progresses, Jax realizes he needs to change his ways to secure a proper future for not only himself but his family and SAMCRO as well. One way we see this starting to happen is Jax transitioning himself into the idea of a "new man." Nijjar's article focuses on the transition of a "new lad" to a "new man." Throughout the show, Clay remains in the "new lad" mindset until the very end. My study will explain the repercussions of that mindset and compare it to Jax, who alters himself into a "new man."

Masculinity has been a recurring theme in the articles I have discussed thus far. Bassett (2014) examines Sons of Anarchy through the lenses of terror management theory and moral foundations theory. Bassett goes into detail about how Jax acts during his tenure as President of SAMCRO. This will be a great article that will help me explain why Jax made the decisions he did. Additionally, within the article, it describes a story arc where Jax engages in deceptive 
measures to move the club in the right direction. The articles I discussed within this section will allow me to describe what a leader should be like and how they can use deception, for the good of the whole or personal gain. This article only examined how Jax uses deception. My study is looking at how deception and leadership are portrayed within the show, but Bassett's article did not focus on the leadership aspect of the show. Therefore, my study would have more variables to look at - as well as analyzing how Clay also engaged in deceptive practices.

Combining the information found within the leadership and deception sections will help provide insight into those areas. Analyzing the deception seen in Mad Men will allow me to compare what has been done with television and deception already. Moreover, I will examine the deceptive practices and see if the motives were the same and what was the result. Despite there being previous research on Sons of Anarchy, none of the research focuses on deception. Most research that is published about Sons of Anarchy deals with Hamlet and masculinity. These studies will be tremendous resources to explain further how these are characteristics a leader must possess - especially a leader of a criminal organization. All the information presented here is imperative to this study. These studies will provide insights and direction as I look at how deception is displayed as a leadership technique in Sons of Anarchy.

\section{Method}

Deception can be utilized in different ways -- it can be used for both positive and negative gains. I want to look and see how Sons of Anarchy portrays deception as a leadership tactic. Therefore, I will be conducting a media analysis to examine the relationship between Jax and Clay - the two leaders seen throughout the series. During their reigns as president, Jax and Clay both had different motives behind why they used deception. I will be examining various story arcs that represent the actions of both Jax and Clay. Newman (2006) discusses that within 
television shows (and other media such as books and movies), there are story arcs, which are when there is a specific story being told over numerous episodes. Since story arcs are spread over multiple episodes, it would not make sense to look at single episodes in a stand-alone way. I chose to analyze story arcs to understand how the show is depicting deception as a leadership technique. I will be examining the events leading up to the leader deciding to engage in deceptive practices, the deceptive tactic itself, and the repercussions of the deception. To do this, I must watch multiple consecutive episodes to obtain all the information needed to complete this study.

After viewing these story arcs, I will go in-depth on which leadership style(s) both Jax and Clay display and discuss how their differing leadership approaches may utilize deception differently. Additionally, I will use the interpersonal deception theory to assist in analyzing how both individuals utilize deception in their daily operations from both a professional and personal perspective. Another theory I will use to assist in my findings will be the leader-member exchange theory. This theory will help me analyze the exchanges between the members of SAMCRO during the tenure of both Jax and Clay's reign as president. Although this is not the approach other researchers took while looking at this show, once this study is complete, I will have shed new light on how Sons of Anarchy portrays deception as a leadership strategy.

\section{Preview of Thesis Chapters}

The next chapter of this thesis will be the literature review. Within the literature review, I discuss the previous research that has been done pertaining to Sons of Anarchy. Additionally, I look at leadership, and how past research will help contribute to the study I have conducted. The next part of the literature review examines deception and explains how I used it for this study. The final part of the literature review explores how other television shows and deception were 
studied. Chapter three is the methods section - this is where I go in-depth discussing how I conducted my study. Chapter four consists of the analysis - this is where I connect what was found in the research and how it is displayed in Sons of Anarchy. The last chapter will be the conclusion - this is where I reflect on the findings and discuss anything I did not expect to arise while conducting this project.

Reflecting on my experience at Jersey Mike's has made me realize that I have no regrets. I am sure there have been times when have been on the receiving end of deception and never was aware of it. But then there were other times where it infuriated me, and I felt like I was taken advantage of - I felt like I was not valued as an employee because management could not be honest with me. As the years progressed, I moved up the totem pole and became the general manager. I found myself engaging in deceptive practices myself once I took a leadership role. As a subordinate, I thought the general manager was using deception as a way of self-gain. On the contrary, once I held a management position, I realized I was utilizing deception for the overall good of the company. This study is looking to explain the stigma associated with deception and trying to shed new light on how it could be used in positive ways. Additionally, I examine how subordinates react to a leader's deceptive practices in a television show and look for evidence of which leadership style is portrayed as utilizing deception most effectively. I will be looking at how subordinates react to deceptive practices and display which type of leader uses deception more effectively. Discovering these findings will allow for organizations, leaders, and subordinates to determine how to act in the workplace to reach success. 


\section{CHAPTER II: LITERATURE REVIEW}

When we take a job with a new organization, we are introduced to a new network of fellow employees. Each hierarchal structure consists of leaders and subordinates who all have a common goal of bettering themselves and succeeding within their organization. This review chapter provides an in-depth look at the concepts that will be discussed throughout this thesis. This chapter will analyze the main concepts of deception, leadership, power, and previous representations in media. Although these are terms that most people are familiar with, there are underlying aspects that will reveal a clearer understanding of what each concept means and how they operate within an organization.

\section{Deception}

Though it has not been recognized by experts as one of the central forms of power in organizations, deception is certainly a powerful - and quite common - strategy that leaders utilize to grasp and maintain power in organizations. Leaders use different forms of power for various reasons - one of those reasons may be to engage in deception. Buller and Burgoon (1996) explain that interpersonal deception theory deals with deception within interpersonal relationships. Three categories of this theory are: falsification, concealment, and equivocation. Falsification revolves around one individual who blatantly lies about information even though they are making it out to be truthful. Concealment is where an individual leaves out pieces of information and refrains from telling the whole truth. Lastly, equivocation is when an individual tries avoiding an issue altogether. Depaulo, Lindsay, and Malone (2003) and Levine (2014) define deception as a premeditated attempt to misinform others - a subset of deception would be lying. Merriam Webster (as cited in Ofen, Whitfield, and Chai, 2016) states that lying is when an individual makes a false statement with intent to deceive others. The terms deception and lying 
are similar and often used in the incorrect context. Deception is a more in-depth thought process where a person will choose which information to withhold and disclose - "This rules out mistaken or unintended lies"(Buller \& Burgoon, 1996, p. 205). Since there is a disagreement between the two concepts, it is important to note that a lie is an individual act, whereas deception is an on-going process or strategy one thinks up as a premeditated tactic.

\section{Motives}

There are various motives for one to engage in deception. Buller and Burgoon (1996) list the three motives of deception: instrumental, relational, and identity. Instrumental motives focus on maintaining power, avoiding punishments, and trying to put damage on the other individual for personal gain. Relational motives revolve around maintaining relationships. In this circumstance, one would use deception to enhance the relationship to the full benefit of the deceptive party or abolishing it altogether. Lastly, identity motives are centered around an individual saving face and creating a stronger self-image (1996). After distinguishing the differences between the various motives of deception, it is essential to note that deception can be used for both good and bad depending on the situation. According to Saxe (1991), there are specific contexts where lying would be acceptable - primarily when it revolves around the good of other individuals. When individuals engage in deception, it is essential that they do not give away any cues that they are trying to deceive the other person.

\section{Detection}

The overall goal of deception is not to get caught in the act. When an individual can get away with deception it is a means of maintaining power. Liars risk being found out - and if they are compromised, they lose power and influence because others will be more suspicious of what they say in the future. Since people are aware that none of us are honest one hundred percent of 
the time, they tend to watch for cues that others might by lying to them. Driskell, Salas, and Driskell (2012) discuss that there are two ways to detect deception: by a polygraph test and decoding cues. According to the National Research Council (2003), polygraph tests are designed to detect physiological alterations in an individual's body that cannot be seen by human observation. Polygraph tests have been criticized in the past, and the validity of these tests has been put into question. These tests are given by a trained professional who can administer questions that put potentially innocent people in a state of distress because of how the questions are structured. Additionally, there are concerns that the polygraph technology has not improved over the years - especially with how technologically advanced today's society has become (Driskell, Salas, \& Driskell, 2012; Meijer \& Verschuere, 2010).

Looking for cues is another way deception can be detected. Driskell, Salas, and Driskell (2012) explain that cues are clues that an individual can give off both verbally and nonverbally that they are being deceptive. Cues are signals that liars send off and receivers read - Most people are aware that people are often nervous when lying in high-stakes scenarios, and that nervousness can be displayed as sweating, twitching, and restless body movements. According to Ekman (1969), there are two broad categories of cues - leakage cues and deception cues. Leakage cues expose what the individual is trying to contain - frequent leakage cues involve facial expressions. Deception cues express that there is a chance deception is occurring without revealing which information is being masked. In addition to leakage and deception cues, there are also two significant categories of cues - thinking cues and feeling cues.

According to Ekman $(1985 ; 1992)$ it is critical for liars to craft their deceptive skills and to leave out any inconsistencies with their stories because that is a cue that deception is occurring. Additionally, if an individual is repeating a story in a slower fashion, there is a likely 
chance of deception taking place. Feeling cues are when an individual understands the behaviors the person engaging in deception is feeling, and it could help determine between deception and the truthfulness. At some point in time, everyone engages in lying. When individuals are lying, they may become nervous or anxious because they fear being caught. As a result, one may display cues that are commonly seen while one is lying. Some examples of these cues would be a higher-pitched voice, the speech has a quicker or slower rate, and there are common mistakes while speaking (stuttering and stumbling over words). When someone else identifies these cues while conversing with someone, and is already doubting the information, he or she is likely to conclude that the other person is lying.

The four factor model is another way an individual can identify cues. Zuckerman, Depaulo, and Rosenthal (1981) explain that the four factor model consists of control, arousal, felt emotion, and cognitive processing. Control revolves around the deception being too perfect. There may be times where the deceptive act is too thought out and comes off to non-authentic enough. An individuals arousal pertains to the nonverbal behaviors one may give off such as rapid eye movements, various ranges in the pitch of the voice, and speech errors. One's felt emotion refers to an individual feeling guilt or anxiety as a result of their deceptive act(s). Lastly, cognitive processing refers to the effort put into pulling off a deceptive act. Deception takes a lot more work compared to telling the truth. Therefore, it is imperative for an individual to know what they are doing and lead with caution if they decide to engage in deception.

Interpersonal deception theory and the four factor model are seen as theories that identify cues. On the other hand, there are two theories that are considered to be non-cue theories: Information manipulation theory and truth default theory. Non-cue theories are theories that 
never address nonverbal behaviors related to telling the truth or the four parts of the four factor model.

\section{Domains}

Due to the difficulties of identifying deceptive cues, people who are looking for these cues use a paradigm on four crucial domains. Investigators must analyze everything they hear and see during interrogations. In some cases, perpetrators will be deceitful toward law enforcement officers because the police are able to punish people - if someone decides to break the law, he or she will most likely not be honest about it. Johnson (2019) explains that an interrogation is when an individual questions another individual in an attempt to reveal information that is being concealed. Therefore, it is the police officers' duties to investigate all the cues they may encounter and note any additional red flags that appear during questioning. It is important to mention that law enforcement officers are not the only people who analyze and look for deceptive practices - citizens and criminals can do this too. According to Navarro (2003), the four domains are: comfort/discomfort, emphasis, synchrony, and perception management.

Comfort revolves around an individual's comfort level within a given scenario. It is noted that people who converse with others they are familiar with tend to portray a more comfortable appearance. When people feel comfortable around others, it is common for them to mirror the image and actions of those they are speaking with, are more inclined to be honest, and to make sure there are no visible barriers that can potentially distract from the conversation. Feeling discomfort is when someone does not like the situation they are in. These people may experience physical symptoms such as heavy breathing, quick heartrates, and rapid eye movements. It is 
common for people to display abnormal nonverbal cues and try to distance themselves from the situation when they are in a state of discomfort.

The next domain focuses on emphasis and how people tend to use it. Researchers found when people are genuine, they show emphasis along with what is being said. Investigators look for various gestures that incorporate multiple parts of the body - both verbally and nonverbally. Liars do not account for emphasis while conversing because they are focused on trying to deceive the other person. When liars try to display emphasis as they speak, it tends to come off as unnatural and does not fit well with what they are saying.

Synchrony is a vital aspect for investigators who are trying to detect deception. Synchrony happens while two or more individuals are conversing, and each person's verbal and nonverbal behaviors are aligning with each other and with what is being said. Most people that engage in deception do not prepare and keep synchrony in mind, so when investigators see this odd behavior, it raises red flags. These red flags become a distraction and lead to ineffective communication because the individuals who was being deceitful could not mask that they were lying.

The final domain of deception is perception management. Perception management happens both verbally and nonverbally and involves statements made to alter the perception of the other person. These statements include, "I never lie," "I would never do such a thing," or "I was always taught to tell the truth." These statements are indicators that the person they are conversing with is potentially engaging in deception. If a person catches these red flags, it is essential to proceed with caution and to question the intent of the one who is being deceitful.

One will engage in deception for one of three reasons: to maintain power, to protect themselves, or to maintain relationships. In any of these circumstances, past research shows how 
it tends to be difficult to identify when these deceptive acts occur. Despite these challenges, experts have published studies that train individuals how to identify both verbal and nonverbal cues to deception and how investigators rely on polygraph tests as another means to decode deceptive practices. Traditionally, this information tends to be associated with law enforcement practices or conversing with others - whether it be in a business or casual setting. Another area where utilizing and decoding deception is apparent is in gang organizations. The information identified in this section will further explain and display messages about deception that appears in the television show Sons of Anarchy.

\section{Leadership}

Workplaces consist of a variety of different people - this could mean some people may adhere to a specific leadership style while others do not. Nanjundeswaraswamy and Swamy (2014) discuss how it is essential for leaders to be able to display various types of leadership styles when necessary. An individual who holds a leadership role needs to possess the ability to adjust leadership styles instead of holding onto a specific one. Khajeh (2018) discusses the six most effective leadership styles and how they affect employee performance:

transformational, transactional, autocratic (also known as authoritative), bureaucratic, charismatic, and democratic. Although leadership and management are both indispensable assets to an organization, this chapter will take a more in-depth look into leadership - more specifically, the transformational, transactional, and charismatic leadership styles.

Are leaders born or made? This is a question that has sparked debates for a long time. A common misconception people have is that leaders and managers fill the same role in an organization. Management is a role that a person may hold, and leadership is a skill one possesses - it is also possible for basic employees to possess leadership qualities. Leadership is a 
skill that enables a manager to be effective in his or her role. Not all managers have leadership skills, and everyone who is skilled at leadership is not always in a management role. Plunkett (1996) defines leadership as the ability to get work done with and through others while winning their respect, confidence, loyalty, and willing cooperation. Unaeze (2003) defines management as the process of working with people and resources to accomplish organizational goals. It is not the manager's responsibility to gain the subordinate's approval. It is not necessary for a manager to possess leadership skills in order to fill this role, but leadership skills will make a manager much more effective in the role.

\section{Transformational Leadership}

There are various general approaches to leadership, and one of those is transformational. Bass (1990) defines transformational leadership as "leaders who broaden and elevate the interests of their employees, when they generate awareness and acceptance of the purposes and mission of the group, and when they stir their employees to look beyond their own self-interest for the good of the group" (p. 21). Bass goes on to discuss how employees tend to see these types of leaders as charismatic. Employees recognize that the leaders focus on establishing strong relationships and ensure that all workers reach their full potential (Bass, 1985). Employees who see this form of leadership present in their place of work recognize that they are not just a number but are valued assets to that organization.

Whenever people hear terms such as leadership, they tend to associate it with white-collar jobs or sports. Although it is highly effective in those fields, leadership is also essential in gang organizations (Leverso, 2019). According to Thrasher (1927), leaders emerge into this role because they are willing to engage in unfamiliar tasks and stare their problems in the eye. The boldness and bravery seen in these actions strengthen the leader's status among the other 
members of the organization. As a result, the other members have found their respected leader. Transformational leadership is also an important leadership style needed in gangs' hierarchal structure. Tita (1999) analyzed how criminal activities start to surround gangs. If illegal activities are happening regularly, the gang needs to be ready for repercussions such as threats and violence. This means that gangs must always be ready to adjust themselves to abrupt circumstances, perhaps more so than other groups. Therefore, it is imperative that the gang's leader possesses the transformational leadership style to adjust to any given moment or circumstance because the gang may need to accommodate their ways of doing things to survive.

\section{Transactional Leadership}

Another common leadership style in organizations is the transactional style. Bass (1985) defines transactional leadership as a process through which the leader makes clear the subordinates' specific roles and required actions, and ensures that they fill these in order to achieve the organizational goals. Individuals who work well under transactional leaders enjoy structure and being instructed on what needs to be done. According to Clipa and Greciuc (2018), transactional leaders set standards in the workplace and cautiously monitor for any potential problems. Odumeru and Ogbonna (2013) state that transactional leadership is mainly passive, and these leaders are not focused on the future success of the organization but on the kinds of current circumstances and pressures that affect the organization's status quo. Despite the strict expectations each member is supposed to reach, every individual is motivated by the potential rewards they may earn. Kabeyi (2018) and Odumeru and Ogbonna (2013) explain that this punishment and reward system is contingent on how subordinates perform their responsibilitiessome rewards may include positive performance evaluation, an increase in pay, a promotion, new responsibilities or a desired change in duties. 
Transactional leadership is a common style to gang organizations as well. Leverso (2019) states that gangs model themselves after real corporate organizations by including the same elements of leadership, face-to-face meetings, coordinated activities, specific member roles, rules, codes, and norms. Therefore, transactional leadership is a leadership style that can be applied to organizations such as gangs - because this is the expected style to see in this lifestyle. When people think of the traditional gang, there is a leader who directs objectives to his or her followers who know exactly what to do in order to reach their goals. It is essential for gangs to remain strong in the moment and to carry out what needs to be done daily to survive. Leverso (2019) further discusses three unwritten objectives of a gang that are vital: to maintain respect, status, and the legitimacy of the gang on the streets. If all three objectives remain intact, then members of the gang will be in good graces with their leader - but if any of the three objectives are not met, there will be repercussions. The objectives are revealed when attempts to attain the goals fail, leading to frustration, anger, and remedial action. The goals of a gang are to produce revenue and remain a dominant force. A few ways gangs obtain those goals are by selling drugs or weapons on the black market and eliminating their competition. These objectives are necessary to maintain in order to achieve these broader goals. Transactional leadership is present in gangs due to the strict coordination of operations and their punishment and reward system.

\section{Transformational \& Transactional}

Even though these two types of leadership styles are distinct and have quite different methods, they are also commonly associated with one another in the workplace. Şirin, Aydin, and Bilir (2018) further explain the differences between transformational and transactional leadership and how they mesh together: 
Transactional leaders view leader-follower relationship as a process of "exchange", and they try to apply existing management techniques efficiently and in parallel with the rules. Transformational leaders both have transactional leadership characteristics and in addition adapt a more future focused management style, give their followers the opportunity to see events with a new point of view, persuade followers to value the targets of the group more than their own personal goals, make the necessary changes and improvements in their organization and question the existing principles and make new principles so that the organization can reach superior performance level (p. 2010). Each leadership style is effective in its own way. Given that criminal activities and unexpected dangers tend to follow gangs, it is up to the leader to decide which style is appropriate to di splay given the context of the situation.

Transactional leadership is a traditional method that leaders have used across time. Although it has worked in the past, due to the chances of unexpected occurrences, transformational leadership has emerged as another option for leaders to use because of the flexibility and willingness to change. Whether it be a corporate setting or gang life in the streets, the leader(s) of the organization must be ready to adjust to their surroundings in order to remain successful.

\section{Power}

Leaders also gain the respect, cooperation, loyalty, and confidence of their subordinates because they have power. According to Robbins and Judge (as cited in Lunenburg, 2012),

"People who have power, deny it; people who want power, try not to look like they are seeking it; and those who are good at acquiring it are secretive about how they got it" (p.1). Power is a construct that is present in multiple aspects of one's life. "Every day, managers in public and 
private organizations acquire and use power to accomplish organizational goals" (Lunenburg, 2012, p. 2). Since power is a critical element in organizational operations, employees across all levels of the hierarchal structure must have a better understanding of the concept. French and Raven (1959) defined power as an influence one or more individuals hold over another individual or group to change their behavior, attitudes, or beliefs. Power is utilized in a variety of ways to achieve the organization's goals - this means there are different variations of power. French and Raven (1959) and Conger and Canungo (1996) identified the different styles of power: legitimate, informational, reward, coercive, charismatic, referent, and expert. Even though each power style may be effective in different circumstances, this thesis will focus on legitimate, informational, reward, coercive, and charismatic power because these types are demonstrated in gang organizations, and the ones that are most apparent in Sons of Anarchy.

\section{Legitimate Power}

French and Raven (1959) define legitimate power as when individual A holds influence by virtue of role or position in the organization over individual B, and individual B is obliged to accept this. DuBrin (2009) provides an example of legitimate power: A supervisor can establish a new policy where all new employees must be approved by said supervisor, which would result in the supervisor possessing authority over the hiring process. It is important to note that a supervisor is someone overseeing other workers. For the most part, supervisors have bosses too. Therefore, it is important to note that supervisors are not the ones who establish legitimate power, but they are granted that power by their superior. In turn, the boss' ability to grant hiring power to the supervisor is itself an expression of power.

People may assume the person who holds the legitimate power is the one calling the shots, but subordinates play a vital role too. Gibson, Ivancevich, Donnelly, and Konopaske 
(2012) found that if subordinates receive a request from a fellow employee that is backed by legitimate power, they would be more likely to do as instructed. For example, if Employee A came to Employee B and said, "The supervisor just put me in charge of cleanup duty, and you need to take out the garbage". Lunenburg (2012) provides a scenario where legitimate power is seen in the incorrect context: A supervisor asking his subordinates to write the project for a class he is taking away from the workplace. This example would be an abuse of power, and the subordinate has the right to decline this action since it is not a regular part of the job. Legitimate power allows a person to demand compliance based on his or her role or position in the company. On the other hand, this person's ability to control the actions of others tends to be restricted to the formal relationship between manager and subordinate. In other words, subordinates will tend to deny any requests that fall outside of the supervisor's official role.

Legitimate power is a type of power where an authority figure directs a subordinate to act on a task. This sort of power can be seen in both traditional workplace settings and gang organizations. Ruble and Turner (2000) explain how the hierarchal structure of a gang serves as a family. In the traditional family setting, the parents serve as the leader and hold the legitimate power since their subordinates (their children) report to them and comply with their directions and demands. Similar to a family, a gang has one or more central leaders (Ruble, 2000). The leader of the gang directs other members on which tasks to carry out - like a chain of command. Due to how the hierarchal structure is set up within gang organizations, it is apparent that legitimate power operates in gangs.

\section{Reward Power}

Another type of power that is common to both traditional organizations and gangs is reward power. French and Raven (1959) define reward power as when an individual can 
influence another individual by providing an incentive in return. Although any kind of reward tends to be seen in a positive light, the employee must value the reward for this type of power to be effective. "Reward power depends on the power wielder (individual or group) administering 'positive valences and reducing or removing negative valences' (Lee and Low, 2008, p. 4). It is often the case that those in a position to offer rewards mistake the value these rewards have for subordinates. If the subordinates do not value the reward being offered, then this type of power will be ineffective. Lunenburg (2012) states "these rewards can be either financial, such as pay raises or bonuses or nonfinancial, including promotions, favorable work assignments, more responsibility, new equipment, praise, and recognition" (p. 3). It is essential to recognize that this reward power must be used appropriately. Workers may be accustomed to the incentives which could develop into a situation where the reward becomes an expectation rather than an incentive. This could lead to an issue of not having workers produce results without a reward being offered, or workers starting to do the bare minimum just to obtain the reward. Leaders must utilize this reward power effectively because the overall goal is to make sure workers produce quality results for the overall good of the organization.

Subordinates are offered rewards from their leaders if they can produce results. In gangs, one of the most effective rewards is being recognized as a full member of the group. Vigil (1996) explains how initiation rituals are a rite of passage and are symbolic - sort of like a welcome to the family. These initiations often comprise beatings from other members of the gangs, and if the person getting beaten can withstand everything, he or she is accepted in. Leverso and Matsueda (2019) provide more in-depth insight into the initiation beatings. Onlookers observe gang members administering the beating, as well as observing the bruises and cuts — "a badge of honor"-left on the initiate. The two symbols establish the initiate as a "homeboy," mark a 
passage to manhood and mark a readiness to engage in gang banging, including fights, raids, and retaliation. This tradition is a test put forth by the leader, and if the test subject passes, he or she is rewarded with membership in the family. These rituals are essentially a form of hazing. Allan and Madden (2012) define hazing as, "any activity expected of someone joining or participating in a group (such as a student club or team) that humiliates, degrades, abuses or endangers regardless of a person's willingness to participate (p. 1)". Therefore, the worse the punishment the subjects endure to be accepted into the group, the more they will value their membership - it is a different reward structure than what functions in the traditional workplace. Reward power is a power that subordinates enjoy because they gain something from their work, and therefore is often a quite effective means of gaining the compliance of one's subordinates.

\section{Coercive Power}

A type of power that is the direct opposite of reward power is coercive power. French and Raven (1959) define coercive power as when individuals perform their responsibilities because they fear punishment or have been threatened by another individual. Workers who endure this type of power tend to resent their workplace environment. According to Lunenburg (2012), coercive power should be used with caution due to its adverse side effects - subordinates start to develop resentment toward the individuals who utilize this method. Some of the punishments commonly associated with this power type are reprimands, miserable work tasks, demotion, suspension, or termination. A form of coercive power that is directly related to this study is withholding vital information, which is a clear use of deception as a form of power. Taking this approach is risky for leaders to make since it could potentially put a strain on relationships throughout the organization. 
Subordinate employees can often possess and express coercive power as well. Lunenburg (2012) discusses how companies rely on the coercive power of their subordinates to maintain employee behavior. Employees have coercive power by utilizing the fear of rejection and using sarcasm against their peers to solidify the group norms of the organization.

While coercive power is certainly not the most effective long-term expression of influence in organizations, it is normal to encounter in gang life. Gang members have strict rules and procedures that must always be followed. Ruble and Turner (2000) explained how gangs have a particular selection process on who can become a real member. Before entry, all potential members must prove they can conform to the gang's rules and norms. According to Kennedy and Baron (1993), the various rules and norms that most gangs have include wearing the correct colors and attire, carrying out their specific responsibilities, controlling and protecting their designated turf (the assigned territory where the gang operates or calls home), and treating the rival gangs as enemies. Like a traditionally run business, if an employee failed to comply with the organization's rules, there would be consequences. In a gang, the punishments can be dramatically worse than those in traditional business organizations. If gang members are found guilty of breaking the rules, the punishments may be immediately losing their status, a beating from fellow members, and possibly even execution.

\section{Informational Power}

Informational power is not one of the original five bases of power that French and Raven first identified in 1959. The sixth base of power was introduced, by Raven (1965), as when one individual can influence another individual based on the content and persuasiveness of their message. This type of power is different from the other types because once the individual who holds the information shares it with someone, the power would disappear. While the power 
associated with a single piece of information is gone once that information is shared, individuals tend to develop power over time in an organization through their ability to continually provide useful and important information to others. In other words, they turn into valued assets to other employees.

Sanders (2004) explains how keeping sensitive information private and having proper organization is vital to the survival of gangs. Newer gangs lack the structured systems that are in place with veteran gangs, and this would cause them to be more susceptible to being targeted by their enemies. "By allowing in either too much information or not enough information, the identity and survival of the system may be threatened" (Ruble, 2000, p. 123). Members must remain silent when it comes to critical information because, in some cases, it could be the difference between life and death. This means leaders could utilize this type of power on newer gangs due to their inexperience - it could be a tactic to dismantle the opposing gang to eliminate competition.

\section{Deception and Power}

Deception and power have been studied together in the past. "Deception has been recognized as a means of influencing through power striving behaviors" (Xu and Schriesheim, 2018, p. 3). According to McDonald (1980), power differentiation can affect the way deception is utilized among individuals based on the status of their relationship. Deception can happen with friends, family, and co-worker relationships. People utilize deception because it gives them power. Lewicki and Robinson (1998) claim that the use of deception spikes the power of the deceiver. People who engage in deceptive behavior must be careful because they could be motivated to use this to their advantage and abuse this power. 
Lindsey, Dunbar, and Russell (2011) discuss the differing motives between subordinates and those who are in a position of power. People who hold power may deceive their subordinates because they feel they have the right to, want to withhold information, or want to motivate them to do something specific. Subordinates who use deception may use it to withstand from any consequences they may encounter, or they use deception for personal gain over their competition.

\section{Deception and Leadership}

Leaders hold a position where they must motivate others to reach a common goal - one way of doing this is by the implementation of deception. According to Payne (2008), leaders utilize deception by telling lies or exaggerating the truth in the workplace for differing reasons. Leaders must be cautious while using this tactic because if they are caught in the act, then the trust with the subordinates can diminish. If members of an organization noticed the person that was leading them engaged in deception, it could hinder employee satisfaction.

Erickson, Shaw, Murray, and Branch (2015) conducted a study that analyzed what a destructive leader is and how they affect organizations. Leaders who are known to engage in deception, change their minds frequently, tell people what they want to hear, and are unable to motivate subordinates are destructive. It was shown that this sort of behavior is worsened over time, and it is hard to break the habit once it is engrained in the person's behavior. "Studies of destructive leadership have shown that there can be devastating effects on individuals, groups, teams, and organizations" (p. 270). It is critical for those in a place of power to identify these destructive habits early on. If this sort of behavior is avoided altogether, a proper workplace environment would exist, and the organization would be closer to reaching success. 


\section{Media Representations of Leadership and Deception}

Leadership and deception are concepts that have been studied for years. Mazur and Kalbfleisch (2003) examined deceitful activity that was present in television families. The results displayed that lying was a common occurrence among television families. Most lies served to protect others and to protect one's self. The father figure of each family was found to engage in deceptive practices around $40 \%$ of the time with the mother figure following at almost half the percentage as the father. Although the deceptive practices may be written into television shows for entertainment purposes, this behavior may ring true to other families around the world who are watching the programs on TV. In Sons of Anarchy, both characters that will be analyzed are father figures. Additionally, the motorcycle club functions as a family within itself. Therefore, the information in this study will provide further insight on how lying is apparent in television families and possibly uncover a more in-depth discovery of the motives behind these lies.

Similar to the previous study, Law (2017) analyzed the television show House. This study showed that the main character engaged frequently in lying. When the main character was in a position of power, he was more inclined to employ deceptive tactics. If the main character found himself in a place where he did not hold power, he tried to win arguments and do whatever he could to regain his power. It is apparent these television programs suggest there is a relationship between deception and power - those that obtain power tend to use it to their advantage by using deception. This study is important to highlight because it identifies the relationship between power and the use of deception seen from a leader's perspective. In Sons of Anarchy, the leaders possess similar qualities as the leader in House regarding maintaining and regaining power. 
Mad Men is a television show that reached mainstream popularity during its tenure. The show focused on people who worked within the advertising agency. Prince (2011) analyzed this television show and inspected the deceptive practices that were present. The researcher found that the underlying motives for deception in this show dealt with relational and identity motives of deception. This article provides a closer look into the differing motives of deception and how it worked out in the workplace. The motives detected in Mad Men, which is a white-collar organization, resemble various occurrences of deception that happens in Sons of Anarchy, which is a blue-collar organization. This would identify that gang organizations function similarly to white-collar organizations.

The shows that these studies have analyzed have had millions of viewers. Therefore, the representations of leadership and deception in media will encourage at least some of these viewers to recognize that deception is an effective leadership strategy. This could ultimately result in these viewers engaging in deception themselves. The information about deception and leadership that are transmitted to viewers by these television shows, such as Sons of Anarchy, are important because they can develop into what viewers expect to be effective leadership.

\section{Previous Research on Sons of Anarchy}

Sons of Anarchy has been the focus of research before but not solely focusing on how leaders of the motorcycle club utilize deception. Most of the previous research deals with representations of masculinity, and the show's similarities to Shakespeare's Hamlet. Wayne (2014) analyzes white masculinities and moral ambiguity through three television series, one being Sons of Anarchy. This article discusses racism and how two characters within the show, the antihero protagonist and the antagonist, display racist characteristics. 
In another analysis of the show, Wood (2016) defined hypermasculinity as "an exaggerated set of cultural norms and behaviors usually associated with males, as a strategy for creating not just legitimacy, but also a scenario of power itself" (p. 330). This is vital because the entire premise of being a member of SAMCRO is brotherhood. Furthermore, masculinity is often displayed as an aggressive response to threats, and there are connections with those who experience these incidents together. The characters on Sons of Anarchy are frequently characterized as having these kinds of experiences. According to Cox (2016), hypermasculinity is present throughout the members of the motorcycle club. Throughout the show, Jax is trying to reign as President of SAMCRO. To do that, he needs to prove himself among his fellow brothers. Displaying hypermasculinity is a way for this to help his case because it would show he is ready to emerge as the leader of SAMCRO.

Wood (2016) further explains the masculine control over oneself and others. For an individual to take control over oneself and their subordinates is a masculine trait that a leader must possess. On Sons of Anarchy, a male's control and dominance, first and foremost, is marked by his ability to have control over himself. While the series places men at the center of the action and thereby in control of most situations, this is mitigated by action that is often prompted by the motorcycle club's need for damage control and attempts to gain "leverage" over others. In other words, motorcycle club members regularly act in response to others' actions. (Cox, 2016, p. 822) Cox does not explicitly link masculine characteristics to leadership, but this study will point out how leaders need to possess masculine characteristics.

Furthermore, like Cox, Nijjar (2018) analyzed the mutated masculinities of protagonists seen in television dramas such as Sons of Anarchy. The researcher is looking to see how one that holds a "new lad" (a man that holds traditional male attitudes) approach alters to more of a "new 
man" (a man that does not hold the traditional male values) approach and how it affects their leadership capabilities. To carry out this study, the researcher conducted a textual analysis to examine specific images of male characters. After doing a textual analysis, Nijjar engaged in discursive analysis to analyze any latent discourses that are seen throughout the materiality of Jax's body - Nijjar goes on to further explain that this is a way to communicate distinct interpretations about hegemonic masculinity. Lastly, a socio-cultural analysis was used to look at the production of the show and analyze the practices of masculinity within it.

Bassett (2014) examines Sons of Anarchy through the lenses of terror management theory and moral foundations theory. Bassett goes into detail about how Jax acts during his tenure as President of the motorcycle club. Additionally, the article describes a story arc where Jax engages in deceptive measures to move the club in the right direction. This study provides a better understanding of why Jax made the decisions that he did. While these studies have covered and explained various perspectives on Sons of Anarchy, they have not analyzed Clay and Jax's use of deception as a leadership strategy - leaving a major gap in our knowledge that this study will fill.

\section{Conclusion}

This chapter analyzed transactional and transformational leadership as they are the two styles apparent in the television show Sons of Anarchy. People who hold leadership positions tend to engage in deception to sustain their power. The aim of this study is to identify how the leaders in the show utilize deception as a leadership tactic.

Combining the information found within the leadership, power, and deception literature will help provide insight into how these concepts are all interrelated. Despite there being previous research on Sons of Anarchy, none of the research focuses on deception. Most research 
that is published about Sons of Anarchy deals with Hamlet and masculinity. These studies will be tremendous resources to explain further how these are characteristics a leader must possess especially a leader of a criminal organization. All the information presented here is imperative to this study. These studies will provide insights and direction as I look at various story arcs and analyze the recurring themes of how deception is displayed as a leadership technique in Sons of Anarchy. 


\section{CHAPTER III: METHOD}

This chapter will reveal the methods took to conduct this study. A synopsis of the television show Sons of Anarchy will be provided as the text of this study. Television shows produce stories throughout continuous episodes. Therefore, this study will analyze multiple story arcs and each arc will be categorized into a thematic analysis. Lastly, each theme will be studies through the lenses of interpersonal deception theory and leader-member exchange theory.

\section{Synopsis of Sons of Anarchy}

Sons of Anarchy was a television show on FX from 2009 to 2014 for seven seasons. According to Littleton (2014), the shows series finale brought in 9.26 million viewers - this broke the show's own record for having the most-watched season on FX. The article also quoted FX's CEO, John Landgraf, stating, "It's a rare and remarkable accomplishment for a television show to generate its - and our channel's - highest ratings in its final season (p. 5)." As for the show's critical response, it holds up at $88 \%$ on Rotten Tomatoes, an 8.6 rating on IMDb and TV.com - which are all respected media critic sites. Due to the popularity and success of the show, at one point in time, streaming services Netflix and Hulu had this show available on their platform. This show reached nearly ten million people while it was airing on cable. Since 2009, Sons of Anarchy has impacted millions of people. Now that the show is available via streaming services, it will continue to influence others for many years to come.

The show focuses on Sons of Anarchy Motorcycle Club Redwood Originals (SAMCRO). A "motorcycle club" is a group of adult men, some younger, some older, who share the connection of being a motorcycle enthusiast. The Mongols and Hells Angels are real-life motorcycle clubs. Both clubs are well-known to authorities and have reputations for partaking in violent and illegal acts. Any group of this nature is frightening to the local community. As a 
result, if there was any influence over local law enforcement officials, they can get away with quite a bit of illegal operations.

The setting of the show is in the fictional town of Charming, California. Within Charming, SAMCRO is seen as a political force - sometimes having more authority than the local police department. Although most residents would be opposed to letting an outlaw group run their town, SAMCRO takes care of their own. It is known that members of the club do not allow others to deal drugs or let violent incidents take place within Charming's borders. The club's relationship with law enforcement allows them to get away with a lot of stuff, which keeps the townspeople a bit afraid of them. Still, because they aim to keep strangers from victimizing the locals, the people of Charming are pretty accepting of the club.

The Sons of Anarchy are an international motorcycle club comprised of various charters located around the world. A charter is also known as a branch. Although Clay served as president for a long time, he was not the founder of the club. SAMCRO was first founded by Jax's biological father, John Teller and Piney Winston. Other recurring SAMCRO members seen throughout the series are Chibs Telford, Bobby Munson, Tig Trager, Harry “Opie” Winston, Carlos "Juice" Oritz, Happy Lowman, and the prospects. A prospect is an individual who is trying to get patched (initiated) into the club but is on a trial run with - this is a crucial period where they need to prove themselves to the rest of the club members.

In addition to the SAMCRO members, various supporting characters are vital to the television story. Gemma Teller is Jax’s mother and Clay's “old lady.” An old lady is another name for a wife or girlfriend of a club member. Gemma serves as the matriarch and has a pivotal role that contributes to the motorcycle club. Like Gemma, Tara Knowles is Jax's old lady and serves as SAMCRO's doctor whenever they need medical assistance. Lastly, it is common to see 
law enforcement officials encounter the Sons of Anarchy. It is known throughout the community that police officers Wayne Unser and David Hale have worked alongside SAMCRO. Although they do not like admitting they turn a blind eye to some of the activity SAMCRO engages in, they have more of an old-school mentality of as long as it is for the good of Charming, then it is justified. In addition to Unser and Hale, SAMCRO deals with other law enforcement agencies throughout the series. The other officials are not from Charming - therefore, they keep a closer eye on the club because instead of seeing the Sons of Anarchy as vigilantes, they see them as criminals.

Like the Sons of Anarchy, there are other gangs present throughout the series. The Mayans are a Mexican motorcycle club located in California. The Mayans are a familiar acquaintance of SAMCRO seen throughout all seven seasons. The One-Niners (better known as the 9'ers) are an African American based street gang based out of California that has frequent interactions with both SAMCRO and the Mayans. Although both the Mayans and the OneNiners are enemies at points throughout the show, SAMCRO's interactions with each gang make up significant storylines throughout the series.

There are scenes within the show where law enforcement officers' question SAMCRO members about their illegal activities. Usually, the responses are along the lines of "we are just a group of mechanics who are motorcycle enthusiasts." Even though that may be true, they are trying to deceive the officers away from the fact that they are part of a criminal organization. The Sons of Anarchy engage in illegal weapon sales, and they provide protection to local businesses. As the series progresses, SAMCRO starts to gain more attention to its criminal operations. Therefore, they start managing a porn studio and escort business to show they are a legitimate organization, but the illegal operations are where a majority of their capital comes in. 
SAMCRO supplies both the Mayans and One-Niners with weapons. Therefore, they try to keep the relationships between the clubs neutral. Even though the One-Niners have a president of their own, they still answer to someone. Damon Pope was one of the most dangerous gangsters in California who oversaw various criminal organizations such as the One-Niners. Pope makes his presence known to SAMCRO after Tig accidentally kills his daughter. After a chain of events takes place, Pope is killed, and his successor is August Marks. Marks is more ruthless and dangerous than Pope - this would eventually turn into a massive problem for SAMCRO.

A reader unaware of the background information of this show would not comprehend the complexity of the overall moving parts. For example, SAMCRO has affiliations with The Mayans and the One-Niners. Despite the fact all three organizations have their differences with one another, the leaders must take control and make sure there is a line of respect between the clubs for business to continue operating. Furthermore, SAMCRO needs to protect the city of Charming, keep good faith with the law enforcement officials -- who are usually investigating them and maintain their personal lives. All of this is a significant responsibility that falls on the leader. Therefore, it is important to examine how Clay and Jax operate within their leadership position because the legacy of the club depends on them, and the utilization of deception could ultimately be the deciding factor.

\section{Data Collection}

This thesis examined various story arcs of how Sons of Anarchy portrays deception from a leadership standpoint. Porter, Larson, Harthcock, and Nellis (2002) define story arcs (also known as narrative arcs) as a continuance of a specific storyline through several episodes. These story arcs may develop throughout an entire season, but they typically start in one episode, continue to build momentum in the following episode, and climax in a later episode. For this 
study, each story arc that was analyzed will revolve around the utilization of deception displayed by the leaders in the television show Sons of Anarchy - Jax Teller and Clay Morrow.

Sons of Anarchy is currently accessible via the streaming service Hulu. The data for this study was collected by viewing all seven seasons (ninety-two episodes) of the show from October 2019 to February 2020. There were instances throughout the series that went unnoticed the first two times viewing this television show. This is because the show was not being watched from an academic standpoint where the goal is to identify deceptive acts displayed by the show's leaders. Each act of deception that involves Jax and Clay was recorded in a journal. Those recorded acts were split into three categories: Deception for one's self-gain, deception for the benefit of the club, and deception for benefit of the one's self-gain and the club. Additionally, these three categories were split into two subthemes: Direct deception and indirect deception. Once I had collected the examples, I analyzed them through a thematic approach.

Braun and Clark (2006) define thematic analysis as "a method for identifying, analyzing and reporting patterns (themes) within data” (p. 79). Braun and Clark identified six phases a researcher must take into account while conducting a thematic analysis: Familiarizing yourself with your data, generating initial codes, searching for themes, reviewing themes, defining and naming themes, and producing the report. Each theme is inspected with two different lenses interpersonal deception theory and leader-member exchange theory.

\section{Theoretical Background}

\section{Leader-Member Exchange}

Lunenburg (2010) describes how the leader-member exchange theory focuses on the relationships built between leaders of an organization and their subordinates. This theory also analyzes how these relationships either enhance or disrupt the workplace environment. Within 
these workplace relationships, there are two groups: in-groups and out-groups. According to Gerstner and Day (1997) individuals that are a part of the in-group report an increase in job satisfaction, improvement in job effectiveness, felt that he or she had access to a higher amount of resources, was more willing to participate in open and honest communication and additional role-behaviors. Those in the in-group are ones who have connected and built a relationship with their subordinate - where those seen in the out-group have not. According to Veechio (1997) and Gerstner and Day (1997), an out-group consists of individuals who feel that access to their boss is limited, have reduced job benefits, fewer chances for career advancement, less access to resources, and are possibly out of the loop on other workplace information. The behaviors associated with the out-group run the risk for an employee to have dissatisfaction in the workplace, which could result in a high turnover rate for the organization.

In Sons of Anarchy, the two leaders analyzed are Jax and Clay. Each individual engaged in multiple acts of deception during their tenure as SAMCRO's President (the leader of the club). Each deceptive act was analyzed, looking for how the act affected other members of the club. The goal is to identify if there were any positive or negative reactions or consequences followed by each act - more specifically, were there specific types of deception that worked better than others. Another observation will be if the person engaging in deception made a difference amongst the members of SAMCRO. As the show progresses, the tensions between Jax and Clay become so prevalent that the deception becomes a regular tactic taken by both leaders.

\section{Interpersonal Deception Theory}

According to Buller and Burgoon (1996) interpersonal deception theory (IDT) focuses on analyzing the reactions and how actual or perceived deception occurs in communication with others. The deception being analyzed is generally in face to face communication, but there may 
be instances where deception occurs with other means of communication. This theory argues that individuals are not as good at detecting deception as they think they are. Interpersonal deception theory consists of three deceptive strategies: falsification, concealment, and equivocation. When one falsifies information, they are sending out false information to another individual - this would be better known as a lie. Concealment refers to when an individual withholds information from someone else. Lastly, equivocation is when a person tries avoiding a situation altogether. Regardless of which type of deception one chooses to engage in, they must remember that employing deception takes a lot of mental effort and is a strategic process. Additionally, when one employs deception, they are doing so for one of three goals: they are looking to accomplish a specific task, they are trying to maintain or establish a relationship, or they are trying to save face. Regardless of their goal, they must keep in mind the consequences that may come as a result of their deceptive acts. This theory is imperative to this study because the aim of the study is to identify how deception is used from a leadership standpoint in Sons of Anarchy. 


\section{CHAPTER IV: ANALYSIS}

Deception is a tactic that is frequently used by people to try and convince others to do something, to cover their tracks, or to even manipulate others for their own benefit. There are several reasons for one to engage in deception, and some are better at identifying it more than others. Since people tend to engage in deception often, they are also likely to engage in deception as a leadership tactic in the workplace. Saxe (1991) explains how using deception is a positive tool in the correct contexts - specifically when it benefits the good of others. SAMCRO (Sons of Anarchy Motorcycle Club Redwood Originals - the original Sons of Anarchy charter) finds themselves in a variety of situations where deception is a powerful communication tool whether it benefits the club itself or the people they are trying to work with. It is sort of like a game because given the context, the deception helps them achieve their tasks. Like the Sons, others in a more traditional work setting have tasks they need to accomplish as well. If deception is a tactic that can assist in achieving those goals, then people would most likely utilize this strategy in the workplace too.

In this chapter, I discover the complexity of deception. Within the television show Sons of Anarchy deception is portrayed as a tool for one's self benefit (when an individual employs deception for an outcome that benefits that same individual) and other times to benefit the group (when an individual employs deception to benefit themselves and the rest of the organization). Interpersonal deception theory has three goals while one engages in deception: accomplishing a specific task, maintaining or establishing a relationship, and to save face. Therefore, these categories of deception fit in accordance to the goals of the theory. Furthermore, each category is broken into sub-categories: direct deception and indirect deception. Direct deception is when an individual blatantly tells a lie of commission to another individual. Whereas when an individual 
engages in indirect deception, they tell a lie of omission or leaving out necessary information to the other person.

The remainder of this chapter will examine examples of each of these types of deception. Furthermore, both motives are approached either by direct deception or indirect deception. Lastly, this chapter will explore the messages about leadership and deception that have been communicated by the show and make meaning of the actions taken by the SAMCRO members.

\section{Previewing the Story Arcs}

To examine the relationship between leadership and deception in the workplace, I analyzed various story arcs depicting how this relationship is portrayed throughout the television show. "The Demise of Opie" story arc begins in Season 1, Episode 4 "Hell Followed" (Conrad \& Gierhart, 2008) and finishes in Season 1, Episode 12 “The Sleep of Babies” (Sutter \& O'Hara, 2008). Opie Winston, a member of SAMCRO, has recently been released from a 5-year prison stint for a crime that he committed on behalf of the club. Despite Opie's loyalty, the president of the club, Clay, still questions his commitment to the patch. Therefore, Clay orders a hit on someone and makes it clear he wants Opie pulling the trigger as a way to test his loyalty. When it is time to make the hit, Opie freezes, and Bobby Munson, a member of SAMCRO, steps in to carry out the execution.

Meanwhile, against Opie's knowledge, the FBI planted a wire in his truck and cell phone and dropped a large sum of money in his bank account. Clay receives word of this and orders long-time club member Tig to kill Opie - and he agrees. After Opie and his wife Donna leave a party at Jax's house, they decide to switch cars. As Donna pulls up to a red light in Opie's truck, Tig pulls up behind her, takes out an automatic weapon, and fires shots to the back of her head. 
As Tig is about to leave, he drives by Opie's truck to confirm he is dead but quickly sees his mistake as Donna lies here dead.

The story arc "Jax's Betrayal” starts in Season 3, Episode 6 "The Push" (Collins, Bush, and Kay, 2010) and concludes in Season 3, Episode 8 "Lochan Mor" (Erickson, Sagal, Sutter, \& Ferland, 2010). Tara Knowles, Jax's high school sweetheart, has rekindled her relationship with Jax - vice president of SAMCRO. The club had stumbled upon prescription pills and asked Tara for assistance in distributing them. As the buy is going down, someone recognizes Tara and Jax and alerts the police. After a raid goes down, Jax fears for Tara's career and ends their relationship that evening. The next morning Tara finds out that Jax slept with another woman.

The story arc "Clay's Speech" begins in Season 4, Episode 4 "Una Venta" (Sutter, Ramirez, \& Gierhart, 2011) and ends in Season 4, Episode 8 "Family Recipe" (Erickson, Dahl, \& Maibaum, 2011). The club endures rapid gunfire while they are talking business in the chapel. One of the gunmen is injured during the attack, falls out of the truck, and is left for dead by his fellow attackers. Instead of killing the attacker, the club finds out he is part of the Lobos Sonora Cartel and tortures him. The attacker snitches on multiple attacks committed by the Lobos Sonora cartel, including the attacks on the Mayans and Sons of Anarchy. Therefore, Jax and Marcus Alvarez, president of the Mayans MC, coordinate an ambush for later in the evening. Earlier in the day, Rita Roosevelt, wife of Police Officer Eli Roosevelt, invited Gemma Teller to a garden fundraiser in Charming, the northwestern town where the Sons of Anarchy motorcycle club is based. Gemma presents the idea to Clay, who ultimately agrees. At the same time as the ambush, Clay is at the fundraiser and gives a speech to the townspeople. After his speech, he provides a large monetary donation in front of the townspeople. 
The "Tara's Attack" story arc kicks off in Season 4, Episode 9 "Kiss" (Corrado, Ramirez, \& Gierhart, 2011) and completes in Season 4, Episode 11 "Call of Duty" (Sagal \& Rodriguez, 2011).Tara and Jax have been arguing lately, and Jax finally decides to make his home life his major priority - so Jax and Tara decide to go for a mini-vacation. Piney Winston is a founding member of SAMCRO, and he has been at odds with Clay over the future direction of the club. In the meantime, Clay catches wind that Tara has been assisting Piney in their feud. Therefore, Clay talks to Romeo, a high-ranking officer of the Galindo Cartel, alone and informs him that he has a problem involving Jax's wife, Tara. Clay makes it clear that this execution cannot be traced back to him and proceeds to give the go ahead to Romeo.

On their mini-vacation, Jax and his family are having a lovely day at the park. A van pulls up, and a couple of men get out and proceed to kidnap Tara. Jax starts sprinting and firing his gun toward the vehicle. Tara is able to get away, but she smashes her hand in the car door during the process. Jax notifies Gemma of the attack, and she starts to get suspicious of Clay. Gemma confronts Clay on the attack, and he beats her bloody. Tig finds out what Clay did to Gemma and steps down as his number two.

The "Home Invasions" story arc begins in Season 5, Episode 11 "Sovereign" (Sutter \& Barclay, 2012) and ends in Season 5, Episode 12 "Darthy" (Collins, Sutter, \& Weller, 2012). As Wayne Unser (Previous sheriff of Charming and friend of SAMCRO) is leaving Gemma's house, the door bursts open, and a group of home invaders beat him. These attacks continue to happen throughout Charming - even resulting in the death of Officer Roosevelt's wife, Rita. In the aftermath of Rita's killing, Clay yells at the three Nomads (Nomads are members of the motorcycle club who do not have specific home charters) making it apparent that Clay is the ringleader of these home invasions. After Unser conducts his investigation, Jax is made aware 
and puts the puzzle pieces together. After Jax confronts Clay, Clay does everything in his power to "make things right" with the club and his loose ends.

The "Damion Pope" story arc begins in Season 4, Episode 12 "Burnt and Purged Away" (Sutter, Erickson, \& Barclay, 2011) and ends in Season 5, Episode 13 "J'ai Obtenu Cette” (Collings \& Sutter, 2012). Opie is irate after learning the truth about his father's death and puts a few bullets in Clay's abdomen. Clay and Jax decide to pin the shooting on the One Niners, a local African American gang, and get him proper medical attention. As retaliation, Tig tries to kill Laroy Wayne, president of the One Niners, but instead kills his girlfriend - who is Damian Pope's daughter. Damian Pope is known to be one of the most dangerous gangsters out of Oakland who has deep political and law enforcement ties.

Tig travels to Oakland to bail his daughter out of an arrest but is tricked and tragically watches Pope and his henchman murder his daughter. The police pick up a few SAMCRO members and send them to prison for the killing of Pope's daughter. In prison, Pope delivers his wants and orders to Jax, which puts him and the other members in heavy waters. Ultimately, Jax makes a deal with Pope and is released from prison after Opie is killed. After their prison stint, Jax and Tig take a ride out to a warehouse in the middle of nowhere. Jax draws a gun on Tig as Pope and his men show up. After Tig is inside the warehouse, Jax starts killing each henchman as he makes his way into the building. Before Pope tries and executes Tig, he realizes Jax has crossed him by killing his men. Jax then hands a gun to Tig, who fires multiple shots killing Pope - only to realize the handgun Jax gave to him belonged to Clay.

The "Piney's Last Stand" story arc starts in Season 2, Episode 10 "Balm” (Erickson, Long, \& Barclay, 2009) and finishes in Season 4, Episode 8 "Family Recipe" (Erickson, Dahl, \& Maibaum, 2011). Piney is not happy with the direction Clay has been leading the club and starts 
calling him on it. Things escalate further once Piney finds out Clay is responsible for the murder of his daughter-in-law, Donna. Piney starts working against Clay by building Jax up for taking leadership of the club and using the letters John Teller, Jax's biological father, left behind to his advantage. Piney threatens to tell the club all his wrongdoings unless Clay kills the drug running for the cartel because the club wants out of illegal activities. The arc ends when Clay approaches Piney at the cabin and tries to amend their situation, but instead fires a shotgun shell through Piney's chest, killing him.

\section{Deception for the Club's Sake}

Deception is frequently utilized in the show to benefit the club, and this deception can either be in the form of direct lies or withholding information - which is a form of indirect deception. I will explore multiple examples of both types of deception being used to benefit the club.

\section{Direct Deception}

The Sons of Anarchy pride themselves on brotherhood. This means they will do everything to protect the reputation of their club - which includes deceiving each other because "it was for the good of the club." A strong example of direct deception for the benefit of the club comes from the story arc "The Demise of Opie.” In Season 1, Episode 11 "Capybara” (Sutter, Erickson, \& Kay, 2008), there is a scene where the members of SAMCRO gather for church. Toward the end of the meeting, Opie addresses his situation (An FBI agent is making him out to be a rat) and pleads his innocence, stating that he is still dedicated to the club.

Opie: Getting squeezed made me realize I can't do this with one foot out the door. I'm here. I'm in. No more doubt, no more mistakes.

Clay: You're a good man, Opie. 
Opie: Am I good with you, Clay? The MC?

Clay: Yeah, we're good. (Sutter \& Erickson, 2013)

As Clay gives his approval, the other members clap, and the meeting is adjourned. But, during their church meeting, Clay has ordered Tig to inspect Opie's truck for any incriminating evidence he could use against him. Tig ends up finding tracking devices in Opie's pick-up truck and cell phone - which were all planted without Opie's knowledge. Although Clay is wrong about Opie being an intentional rat, this solidifies his doubts in Opie and labels him as the rat. Clay saying "we're good" is an example of direction deception. Clay is telling a lie to the other members of the club to protect them from a presumed rat and he is also lying to Opie. He does not want Opie to know that he suspects him, so he can keep poking around for evidence of Opie's betrayal.

Another example of direct deception for the benefit of the club is seen in the story arc "Damian Pope". In Season 4, Episode 13 “To Be, Act 1" (Sutter \& Collins, 2011). Opie learns of his father's death, and races to the clubhouse, in search of Clay. Opie finds him in the chapel and fires two shots into his chest. In order to keep Clay alive and to protect Opie (although Opie attempted to Kill Clay, he is still a SAMCRO member so they will do what they need to protect him), Jax and Clay come up with a cover story to tell the authorities when medical professionals arrive. Then, Jax and Ratboy, a prospect (someone who is on a trial-run with SAMCRO), carry Clay to a location outside the clubhouse to make the story add up. Jax looks at Ratboy and says, "if you ever want to make patch - it was two black guys that shot outside the garage (Collins \& Sutter, 2011)."

One of the biggest dangers of deception is, of course, the fact that lies often require additional lies to cover-up the original ones. In this instance, Jax and Clay directly lie to other 
SAMCRO members, people associated with the club, and the authorities. Since everyone was directly told to believe that the "blacks" were responsible for this, Tig took it upon himself to avenge his fellow brother - because that patch signifies brotherhood amongst these men. Tig attempted a drive by killing on Laroy but misses and killed his girlfriend. Unfortunately, the girlfriend is the daughter of Damian Pope - one of the most notorious gangsters in Oakland who oversees multiple gangs, including the One-Niners. The point is, if Jax and Clay did not directly lie to everyone, the horrid chain of events that unfolded would never have happened - some events which are included as parts of this study. This section shows how members of the club use direct deception for the sake of the club - in both cases, there is a pattern of members directly lying to other members trying to protect them from a bigger issue at hand.

\section{Indirect Deception}

Even though the club prides itself on brotherhood and considers its members to be one large family, there is a large amount of indirect deception for the benefit of the club that happens behind closed doors. In a sense, the characters do believe it is sometimes necessary to lie to each other to maintain that brotherhood. A strong example of indirect deception comes from the story arc "The Demise of Opie." In Season 1, Episode 11 "Capybara” (Sutter, Erickson, \& Kay, 2008), Tig informs Clay about finding tracking devices in Opie's possessions, so they both question what to do. Instead of bringing this to the club, they decide to handle things themselves - off the books. Both men agree to kill Opie, in honor for the club and Bobby Munson who is a member of SAMCRO who is held by the authorities for the murder Opie failed to carry out. Even when Jax comes to Clay after the club talked with Opie, he directly tells Jax how he believes Opie, and everything is squashed. Clay and Tig are indirectly deceiving everyone by making it seem like all is well and withholding the information of finding the trackers inside Opie's belongings. In 
reality, finding the trackers convinces then that he is the rat, and they plan his execution because eliminating a rat will eliminate a threat to the club. This is another occurrence of when Clay tells a direct lie, and it leads to several repercussions down the road.

Another example of indirect deception comes from the story arc titled "Damian Pope." For some time, Opie has been acting recklessly due to the loss of his wife and father - he feels lost. Others around the club have taken notice because Opie has been putting himself in neardeath situations. In Season 5, Episode 3 "Laying Pipe” (Nunn, Sagal, Sutter, \& Arkin, 2012), Jax and Pope have a sit-down meeting at the prison. Pope provides Jax with his conditions if he wants to remain alive - Pope wants fifty percent of SAMCRO's cartel earnings, Tig remains in jail for life, and he needs a dead son.

Now Jax is tasked with choosing what to do and who dies. As Jax and Opie are in their cell, Jax says, "I'm treading water here, Ope - I got no idea how to keep everyone alive (Nunn, Sagal, Sutter, \& Arkin, 2012).” Jax confesses everything he has been withholding from the club to Opie so he could understand the circumstances of everything that has happened. As it comes time to pick their fate, Jax says, "I don't give a shit who Pope is - or how deep his reach is - he doesn't make that call - we decide our fate. (Nunn, Sagal, Sutter, \& Arkin, 2012).” As the group prepares to fight back against the guards, Opie rushes ahead and headbutts one of the guards. His headbutt is the signifying factor that he is the one that will die. After hearing Jax confess everything and hearing out his plans for the club's future, Opie knows Jax needs to continue. Opie withheld the decision to sacrifice himself from Jax because he knew as a leader and best friend, he would never let Opie die. But Opie saw past that and knew this was his way to get back at Clay - sacrifice himself to let Jax continue and take Clay down once and for all. 
In the story arc "Piney's Last Stand," Piney engages in indirect deception for the benefit of the club. In Season 4, Episode 3 "Dorylus" (Corrado, Sagal, \& Weller, 2011) and Episode 4 "Una Venta" (Sutter, Ramirez, \& Gierhart 2011), Piney separately approaches Tara and Gemma. In both conversations, Piney expresses his concern about Clay bringing the club down the wrong path. In Gemma's conversation, Piney tells her Clay agreed to mule cocaine for the cartel, and she needs to talk some sense into him. When Piney is working with Tara, he is looking for leverage on Clay because he feels that Clay will continue to be power-hungry and ruin

\section{SAMCRO.}

Talking to other members' "old ladies" about club business is a big no-no. After the vote to mule the cocaine passes, Clay walks over to Piney and says, "You ever try to end-run me through my old lady again, I'll slit your throat (Corrado, Sagal, \& Weller, 2011).” The tensions between Piney and Clay are at an all-time high. Piney has made it clear Clay's leadership skills are not what they used to be, and the power has corrupted him. Clay sees Piney as a threat, and the longer this feud goes on, the more desperate Clay becomes to retain his power as you can see him now threatening to murder Piney.

The next example of indirect deception revolves around Bobby and Jax in a story arc called “Home Invasions.” In Season 5, Episode 9 “Andare Pescare” (Sagal, Sutter, \& Gierhart 2012), SAMCRO votes to have Frankie Diamonds, one of the Nomads who joined SAMCRO, meet Mr. Mayhem (death). But Jax decides to withhold the information about Clay leading the home invasion attacks from the other members of the club. Instead, he has a meeting with Bobby - where he brings Bobby up to speed on what else is happening. Roosevelt told Jax there is a rat at their table, and in exchange for that information, Roosevelt wants Frankie Diamonds for the murder of his wife. To keep Diamonds alive, Jax said he and Bobby would do the killing in an 
isolated area, but instead, that is where they would make the swap. At first, Bobby is hesitant; he says, "that's a lot of moves - that's a lot of lies (Sagal, Sutter, \& Gierhart, 2012)." Usually, those in the outlaw world do not typically help law enforcement because they are enemies. But, Jax and Bobby decide to work with Roosevelt because having a rat at the table is detrimental for the future of the club.

Another example of indirect deception comes from the story arc called "Piney's Last Stand." Ethan Zobelle and AJ Weston are the two main antagonists of season two. Both men are at the head of a white supremacist group and have a problem with the Sons of Anarchy for dealing weapons to people of color. Therefore, Weston and his men abduct and gang-rape Gemma repeatedly as a message to SAMCRO to quit dealing with other races. Instead of telling Clay and Jax what she endured, Gemma decides to withhold from telling them because she thinks she is now holding power over Zobelle by not giving them what they want. In Season 2, Episode 10 "Balm" (Erickson, Long, \& Barclay, 2008), Gemma finds out Jax has the approval to go Nomad. She knows how vital Jax's leadership is to the club, so she finally decides to sit both men down and confess what has happened to her. She only decides to reveal what happened to her to manipulate Jax into staying with SAMCRO because she too knows that Jax needs to overthrow Clay as president of the club.

Continuing in the "Piney's Last Stand" story arc, Piney has had enough of Clay and takes things into his own hands. In Season 4, Episode 5 "Brick” (Erickson, Dahl, \& Barclay, 2011). Clay and Piney have a discussion together in the chapel. Piney informs Clay that the original intentions or the club were never to touch drugs. He continues to tell him that the club is supposed to be moving out of illegal activities. Piney then uses the leverage Tara gave him and questions Clay on the killing of JT and Lowell Sr. (JT's personal mechanic). This enrages Clay 
and Piney provides Clay with an ultimatum - kill the drugs and relationship with the cartel, or the club gets the letters (John Teller wrote letters identifying the troubles in Charming and if he were to ever die it would be at the hands of Clay and Gemma). And before Piney leaves he tells Clay that he has one week to decide, and if he kills him, there are contingencies in place for the club to receive the letters.

Piney's ultimatum strips Clay's power away because both options will result in a loss for Clay. If Clay kills the cocaine movement, his retirement will not be financially stable, and if the club gets ahold of the letters, he will be meeting Mr. Mayhem. Piney could have gone directly to the club with the information he had with the letters but decided not to. Even though this is a club matter(JT's death and other histories), he wanted to provide Clay one last opport unity to make the right decision and shed light on the man he once used to be. Maybe if Piney did not try and handle Clay on his own, he might be alive to this day.

Clay is at a point where his lies are starting to go deeper and deeper - the people around him are beginning to question his moves. Clay's objective is to protect his ultimate secret - he killed John Teller - and remain president. If Clay never ordered the hit on Opie, Donna would never have died, and the feud with Piney would not have escalated to the point of Clay killing him. Clay is in a desperate position to retain his leadership and he will do everything in his power to secure his loose ends - even if it means trying to kill another member's wife and his daughter-in-law.

This section of the analysis covers various examples of indirect deception for benefit of the club. In Sons of Anarchy this type of deception tends to be more common. The members try and take matters into their own hands and seek out justice because it was "for the club" or the 
"greater good" - therefore believing their actions would be justified even though they are deceiving each other.

\section{Deception for Self-gain}

In addition to engaging in deception for the benefit of the group, people also employ deception for their own self-gains. Like using deception for benefit of the group, when one engages in deception for their own self-gain, it can be in the form of telling direct lies or withholding information.

\section{Direct Deception}

One case of direct deception in Sons of Anarchy stems from the story arc "Home Invasions." The town of Charming has fallen victim to a series of home invasions. People are starting to point fingers toward the Sons of Anarchy for having some sort of involvement because of their criminal past. The Sons deny all allegations against them for being involved but they still offer to investigate the matter. In Season 5, Episode 11 "Sovereign" (Sutter \& Barclay, 2012), the episode ends with a "crippled" Clay walking up to the door of his house, pulling out the oxygen tubes, looking in the direction of the new Nomad recruits, and yelling, "Idiots! You weren't supposed to kill her (Sutter \& Barclay, 2012)!"

At this point, the audience knows Clay is the one responsible for the home invasions and the death of a pregnant Rita Roosevelt. This shows how desperate Clay is to recapture his position as president. Clay hates how he does not hold any power anymore, so he had three outsiders patched into SAMCRO to carry out these horrific crimes. Clay is doing this to sabotage Jax's tenure as president, so the others think operations were smoother when he was at the head of the table. 
Clay engages in multiple deceptive acts in the "Home Invasions" story arc. Another example comes from a conversation he has with Tig. In Season 5, Episode 11 "To Thine Own Self" (Daniels, Barcheski, Sutter, Barclay, 2012), Clay expresses how he misses having Tig at his side and offers him an opportunity to regain what they once had. Clay admits his wrongdoings and offers him some lucrative opportunities behind the club's back - one being taking out Pope, the man who brutally killed Tig's daughter. Tig ultimately declines the offer as he walks out on Clay.

This is one of the points in the series where Clay is not who he once used to be. He is still trying to wheel and deal on his own, but nobody is following with him - which leaves him powerless because there is power in numbers. Tig declining to help Clay expresses how Clay's leadership skills have diminished and how the club has moved onto a new leader. Tig is sick of how things used to run, too, and declining an opportunity to take out the man who killed his daughter shows how much trust and faith he sees in Jax. Another deceptive act appears in the story arc "Piney's Last Stand. "In Season 2, Episode 10 "Balm" (Erickson, Long, \& Barclay, 2009), Clay and Opie are on a task together and converse for a few minutes. During their conversation, Clay tries to manipulate Opie into thinking Jax is too hardheaded and should be more open to advice from others. Additionally, when Opie confides that he has been struggling with his wife's death, Clay continues to cover his lie and has Opie go back to the clubhouse.

Clay understands that Jax will take over leadership of the club, but he is doing everything in his power to avoid the transfer of power for as long as he can. Therefore, Clay is continuously seen trying to tie up his loose ends and deceive other members in the process - instead of being honest with them. People in a position of power think deception is a tactic to use for more significant gains, but deception can be dangerous with how simple it is to keep compounding 
each lie as it continues. Eventually, the lies will become so deep where Clay will not be able to save himself. As a result, the subordinate club members will not want to work under him - Clay will lose group control and be forced out of his leadership position if his behavior continues.

Another example from the story arc "Piney's Last Stand" involves Clay and Piney. In Season 4, Episode 8 "Family Recipe" (Erickson, Dahl, \& Maibaum, 2011), Clay knocks on Piney's door at the cabin. Piney answers with a loaded shotgun in hand. He de-arms Clay and lets him inside. Clay informs Piney he needs more time before he can get the club out of the cartel business, but Piney does not approve. Piney discusses how back in the day Clay could be trusted and how he was his sponsor into SAMCRO. As Clay makes his exit, he burst through the door before Piney could lock it, and proceeds to kick him across the face. Clay then grabs ahold of Piney's shotgun and fires a round into his chest - killing him. Clay continues to look around the cabin for the letters but could not find them. Before he left, Clay dips his fingers in Piney's blood, and writes "LS"- meaning Lobos Sonora Cartel - on the First 9 picture.

Clay's web of lies has become quite large, and he is starting to lose control of it. Piney mentions how Clay used to be a trusted person among everyone, but power can potentially corrupt individuals - and in this case, it did. Gemma once warned Piney that Clay would kill him if he kept investigating what happened to John Teller, and he responds by saying, "that's half the reason I'm doing this"(Erickson, Dahl, \& Maibaum, 2011). Because after reading John's letters, Piney knows Clay is responsible for his death and the slow demise of SAMCRO. Piney has always said he had contingencies in place for if he somehow died. Piney's death would symbolize everything he has done to take down Clay has worked, and it would alert others that the suspicions were right about Clay being the root of all evil for SAMCRO. This goes to show how desperate Clay is for retaining his power. When he pins the cartel for the murder of Piney, it 
shows he has lost all love for everything he once stood for. Not only did he kill Piney, who was a founding member of SAMCRO and Clay's sponsor but pinning the murder on the Lobos Sonora Cartel will only spring a new web of lies and more bloodshed amongst SAMCRO.

This section of the analysis deals with direct deception for one's self-gain. There are recurring patterns in these examples that show if someone is desperate enough to retain their power, they will engage in all sorts of deception in order to do so.

\section{Indirect Deception}

Continuing in the story arc "Piney's Last Stand," Jax and Clay decide to come to an understanding. In Season 4, Episode 2 "Booster” (Erickson, Collins, \& Ferland, 2011), Jax and Clay are meeting with Marcus Alvarez and two members of the Galindo Cartel. At the end of their meeting, Romeo confirms with Clay that their cartel will start purchasing weapons from SAMCRO and how the Sons will be moving cocaine for them on occasion - this angers Jax.

Clay: I need you to understand this.

Jax: Understand what? That you forgot to mention that we would be running coke for the Galindo Cartel?! We voted in selling them guns!

Clay: We'll have another vote.

Jax: You brokered this whole goddamn thing in Stockton - you kept us out of the loop on purpose.

Clay: The Russians needed to die for what they did to you inside. The Galindo Cartel is the only player big enough to keep the Russians off our backs.

Jax: Oh, don't give me the I did this for you some bullshit. This isn't about me, Clay, and it isn't about the club, this is about you cashing out. 
Clay: These last two years were brutal for your mom and me: no savings, no medical, no retirement cushion. I got, what, a year? Maybe two? I've given my whole life to this club. I don't want to walk away with nothing.

Jax: What do you want from me?

Clay: This vote, splits the ranks. I want you to back me, it's the only way this thing passes.

Jax: If I do this, I'm out when you're out.

Clay: What are you talking about? You've wanted the gavel your entire life.

Jax: Not anymore

Clay: What are you going to leave SAMCRO? What the hell else you going to do?

Jax: It doesn't matter. I need your word you let me walk away - no recourse. (Erickson, Collins, \& Ferland, 2011).

SAMCRO has always stated that they would never dip their hands in the drug trade. Until now, that statement rings true, but Jax sees this as an opportunity for himself too. Clay wants into the drug business strictly for profit because he feels like he is entitled to a pay-off for all his dedication and loyalty to the club. Knowing how the other members think about the drug industry, Clay decides to move forward with accepting Romeo's offer anyway. Even though this will cause tensions amongst the club, Clay tries to spin it how it will benefit the club. Jax quickly shuts that down and calls him out for making this move strictly for himself. In exchange for letting Clay deceive the club, he informs Clay the only way this happens is if he grants him a release from SAMCRO with zero repercussions. Jax knows not all members would vote him out of SAMCRO since he is supposed to be the successor once Clay steps down. This is his one opportunity to remove himself from this lifestyle and try to make a better life for not only 
himself but his family too. Even though both men are deceiving the other members of the club, they are both doing so strictly for self-gain.

The final example of indirect deception stems from the "Damian Pope" story arc. In Season 5, Episode 13 "J'ai Obtenu Cette" (Collins \& Sutter, 2012), Jax apologizes to Tig, saying he could not tell him what was going on because he would have picked up on something. Then, Tig notices that the gun he used to kill Pope belongs to Clay. If Damian Pope was ever to be killed, he has a plan in place that put the triggerman's head on a five-million-dollarbounty. Jax asks if that would be a problem for him, and Tig declines. Later in the episode, Bobby enters the chapel and says to Jax,

Bob: I know what you did with Clay. I just talked to Juice and Tig.

Jax: What'd they say?

Bob: Nothing.

Jax: I kept my word to you and the club; I didn't put a hand on Clay.

Bob: It wasn't about being smart enough to hurt him; it's about being smart enough not to hurt him. You had a chance to be different.

Jax: *Chuckles* Maybe I'm not so different. (Collins \& Sutter, 2012)

Jax is at his wits' end with Clay and decided to knock out to problems with one stone. Once Opie died, Pope was a dead man walking. But, Jax had to be careful on how to approach offing him because of the five-million-dollar bounty for the triggerman. Therefore, Jax drew up the scheme of going out to this location in the middle of nowhere because it was a secure and quiet place to carry out the hit. When the cops find the murder weapon, the evidence will point toward Clay as Pope's killer. This would tip off Pope's hit men and eventually eliminate Clay as a problem for Jax. 
This section of the analysis examines two examples of indirect deception for one's selfgain. Both examples revolve around the show's leaders trying to make bigger moves without the club's knowledge for a bigger payoff in the long run.

\section{Deception for both the Clubs Sake and Self-gain}

Thus far, this chapter has identified two different types of deception one may utilize deception for self-gain, and for the benefit of the group. Now I will analyze deceptive acts represented in Sons of Anarchy that are engaged as a means of benefitting both the group and one's self-gain. There are certain circumstances where leaders engage in deception where they are deceiving themselves by thinking they are lying to benefit the club, but in hindsight, they are only benefitting themselves.

\section{Direct Deception}

Clay continues with his deceptive acts within the "Big Speech" story arc. In Season 4, Episode 8 "Family Recipe" (Erickson, Dahl, \& Maibaum, 2011) the club members were at church in the chapel. During their meeting, the chapel endures rapid gunfire. A pick-up truck storms their complex and starts firing upon all the SAMCRO members. Additionally, someone attacked a Mayan owned truck and stole their drugs. This unites Jax and Marcus Alverez, the president of the Mayans MC, to torture the injured Lobos Sonora (cartel) member until he provides information on the attacks. After the attacker suffers through some torture, he snitches, revealing who the leak in the Mayans club is. Before taking out the rat, Jax and Alverez scheme together a plan to feed the rat false information and kill as many Lobos Sonora members that show up later that night.

Later in the episode, as the club is taking part in their scheme, Clay is at the garden's fundraiser for the town of Charming. During his speech, he made it known he is aware that the 
public has their concerns about the motorcycle club. After expressing his gratitude and love for the town of charming, he made a monetary donation of $\$ 75,000$ on his behalf and Elliot Oswald - who had a stint at trying to become the mayor of Charming.

Although the club used the fundraiser as a cover for their retaliation on the cartel, think about who looks like the good guy in this scenario - this is a PR stunt for SAMCRO and especially Clay. When the club members are off committing their crimes, Clay is the one member who is at the center of attention. He has position himself to look like the protagonist to Charming by expressing his love for the town and presenting a $\$ 75,000$ check to the gardens. Additionally, if the attack was to be intercepted by law enforcement officials, Clay has positioned himself where he would look innocent in all of this since he had multiple alibies.

This section of the analysis analyzed direct deception for one's self-gain and for the sake of the club. This type of deception is a strong tactic for leaders to use because it knocks out two birds with one stone - their deceptive act will not only benefit their individual goals, but at the same time achieve a greater good for the benefit of the organization.

\section{Indirect Deception}

The first example of indirect deception to benefit both the individual and the club comes from the story arc "Jax’s Betrayal.” In Season 3, Episode 6 "The Push" (Collins, Bush, \& Kay, 2010), the club takes possession of some illegal prescription pills. Trying to make a profit on them, Clay asks Jax if he could ask Tara to help move them - Jax instantly refuses. Jax is hesitant because Tara is a surgeon; she has an established career; he does not want to jeopardize her success by bringing her into the illegal club business. Despite his concerns, he brings the opportunity to Tara again, and she agrees to help. 
When Jax and Tara are outside a medical facility selling the drugs, a witness that feels indifferent toward the Sons sees the deal go down. The witness informed Officer Hale of what he has seen, which leads to a raid on SAMCRO's clubhouse in a failed attempt to find the drugs. The raid put things into perspective for Jax and frightens him - not for his sake, but Tara's. That evening, Jax tells Tara what happened and ends up breaking things off between them because he did not want her or her career to get hurt. The episode ends with Jax having sex with one of the porn stars, Ima, in the back room of the clubhouse. In Season 3, Episode 8 "Lochan Mor" (Erickson, Sagal, Sutter, \& Ferland, 2010), opens with Tara entering the clubhouse, making a beeline for the back room to find out that Jax has betrayed her the previous evening.

Jax decides to do this for several reasons. First, Jax does not want to break things off with Tara romantically, but he sees that if he does not, she never will. Jax knew Tara would come looking for him, that is why he was not sneaky about it - he wanted her to find them so she would leave him and make a better life for herself. Their lifestyles could not be any more opposite of each other, and if she is caught up in the club's illegal activities, then her career would be over, and she would possibly face jail time. The next reason Jax slept with Ima was to secure a future for his boys. Tara and Jax are always arguing about the well-being of their boys, and Jax's lifestyle is a significant threat to them. Therefore, he knew she would take their two sons with her and provide a better future for them so they would never follow in Jax's footsteps. Lastly, this action would help the club in the long run. Tara has always been the one to question Jax's actions and talk sense into him. This has caused tensions between Jax and other members of and close to the club. With Tara out of the picture, this would eliminate her always questioning what he is doing, and it will allow for club operations to run smoothly. 
Another example of indirect deception stems from the story arc "The Demise of Opie." In Season 5, Episode 3 "Laying Pipe” (Nunn, Sagal, Sutter, \& Arkin, 2012), Jax and Tig have a conversation after Opie is murdered.

Tig: I'm sorry, Jax. I know it should have been me in the box.

Jax: But it wasn't...I talked to Pope - the witnesses that put you killing his girl go away. You're coming out with us.

Tig: You got me cleared?

Jax: Yes, I did.

Tig: Thank you, man.

Jax: It's not about thanks. For now on you back my every play, you support all my ideas, and you never vote against me again.

Tig: You got my word brother. (Nunn, Sagal, Sutter, \& Arkin, 2012)

Jax has been trying to end Clay and move the club in the right direction for a while. Tig knows he is indebted to Jax for what he has done for him, but this conversation proves to Tig how powerful Jax is. Jax has ultimately placed Tig as his yes-man. This action allows Jax's vote to serve as two votes now. Jax can use the advantage he has in one of two ways: he can use Tig as means to push the club forward on future votes, and if Jax ever wanted to deceive the club in the future to benefit himself - he will always have Tig to back him.

This section of the analysis examined indirect deception for both benefit of the club and one's self-gain. Sometimes there are actions that need to be taken by individuals for a greater outcome to occur and a means of accomplishing that can be through the utilization of indirect deception. 


\section{Analysis and Discussion of Findings}

Burgoon and Buller (1996) state that when one engages in deception, they have information to keep track of, they need to control their behavior, and they are responsible for image management. Despite Clay's early successful years as president of SAMCRO, he did a poor job at all three things. There were numerous times when Clay would make it known the piece of information he has can never be traced back to him - and it is. When Clay orders the execution of Tara Knowles, this information is traced back to him by his wife, Gemma. Additionally, Clay's behavior was sporadic. At one point, he is happy and treats Jax with pure grace, but he wants to kill him in the next moment. It is vital that leaders - especially leaders who engage in deception - are able to maintain control of their behavior. If a leader is known for losing control of their behavior, they are showing off a poor image of themselves and they are much more likely to reveal their deception in one of these out-of-control outbursts. Image management is another aspect Clay was unable to keep up throughout his run. Toward the end of his attempts at regaining his power, his image descended, and people knew he was a deceitful man. Therefore, his credibility was scarce, and his former subordinates lost trust in him.

Jax emerged as a strong leader before he was ever named president. Jax was the source of all the information within SAMCRO, and he did a phenomenal job at maintaining all of it. He made sure people knew only the amount of information that was necessary for them to know. This was smart on Jax's part because this does not allow them to have access to any additional information that could hurt the club further down the road. Additionally, by maintaining information, Jax is securing himself as the strongest person within the club since he has the knowledge. For the most part, Jax does an alright job at controlling his behavior. There are times where he loses his temper and acts on impulse, but I would not say it is a complete loss of 
control. Even if he gets to that point of loss, he always finds himself a way to rejuvenate himself into a better scenario than he was once in. Lastly, Jax did a fantastic job at his image management. Jax always prided himself on being the one who moved SAMCRO in the correct path, and there were numerous times where he questioned himself on this. Although there were various scenarios where Jax was in the wrong, he always made sure to make things right because he knew he had to live up to the SAMCRO's reputation. While looking at interpersonal deception theory and the patterns pertaining to information maintaining, controlling behavior, and image management, Sons of Anarchy displays transformational leaders do a better job at these conducting these three things, while transactional leaders tend to struggle with them.

\section{Discussion of leadership styles in SAMCRO}

Jax and Clay serve as the two foremost leaders throughout the show's tenure and those who engage in the most deception. Although both leaders shared a passion for SAMCRO (Sons of Anarchy Motorcycle Club Redwood Originals), they both display different leadership styles. Clay's actions depict a more transactional approach where leaders see workers as expendable, they do not focus on the future of the organization, and they want things done in a specific manner at the present time. Jax displays a more transformational approach where the leader focuses on the future goals of the organization, incorporates their subordinates in change, and are open to trying new approaches in the workplace. I do want to note that there are times throughout the show where both men show signs of both leadership approaches. But, for the most part, Jax is the one who portrays the more transformational approach, and Clay displays the transactional approach.

Throughout the show, the Sons of Anarchy find themselves in a variety of scenarios where leadership is crucial for success. A leader needs to identify the situation at hand and adjust 
their leadership approach accordingly. Before conducting this thesis, I did not have a definite opinion on whether transactional or transformational leaders were more likely to engage in deception. This show suggests that those in power who display a transactional leadership style tend to engage in the most deception. Clay was one of the original members of SAMCRO and has served as club president for many years. Due to Clay's long tenure with the club, he holds a more "new lad" (a man who holds traditional male attitudes) approach, which gets in the way of some of his decision making throughout the show. Possessing a "new lad" way of thinking and acting filters into his leadership skills and makes him hesitant to change. There are times throughout the show where Clay's power and leadership are threatened, but instead of adjusting his leadership skills to accommodate those obstacles, he sticks to what he knows, thinks is right, and deceives others his way.

After viewing Sons of Anarchy, it is apparent that the transformationalleadership approach is the better leadership style better suited to utilize effective deception. As seen in the show, those that display a transactional approach are used to their structured way of doing things and are more hesitant to change because they do not focus on the future success of the organization but on how things are doing at the present time. These types of leaders want things done their way, and those who are assisting in carrying out these tasks are seen as replaceable. For example, when Clay is desperate to retain his power, he approaches the three Nomads to assist with the home burglaries to make it look like Jax is not fit to protect his own and the town of Charming. When things started to go south, he takes matters into his own hands and kills off the Nomads. Sons of Anarchy is portraying that transactional leadership can be reactionary since Clay has to continue covering up his lies in the heat of negative situations instead of planning out what he wants to do ahead of time. In comparison to a traditional business, this would be like a 
manager firing subordinate employees. If the employees are not reaching their goals, management will always be able to find someone to replace them.

Utilizing effective deception is more important to those who display a more transformational approach. Transformational leaders look at the future for the success of their organization, and within the time it takes to reach those future goals, there are frequent occurrences that come into play. These leaders need to adapt each time these obstacles appear and use deception strategically. These types of leaders do not see their subordinates as expendable as transactional leaders do, so the relationships need to be built on. Sometimes these leaders can even develop the relationships with the use of deception if it helps achieve the end goal for the future success of the organization.

Furthermore, Sons of Anarchy portrays deception as a tool that is needed for effective leadership. For the most part, deception is something that most people endure daily. Whether it be for personal gain or benefit of the group, deception is apparent in most people's lives. Leaders must be able to use deception strategically because there will be times when challenges appear, and deception might be their only way to win these challenges. Even though anyone can utilize deception, it does not always turn out to be a successful tool for everyone. Clay arguably uses deception more than anyone in the show, and most times he does, it backfires. Clay is so wrapped up in his power trip, and anytime he feels his leadership position is threatened, he will go to great lengths to protect himself. Clay's deceptive behavior has a pattern where each time he engages in deception, it magnifies into something worse, and it eventually turns into a massive slippery slope. This is a result of his transactional leadership style and "new lad" approach. If Clay alters his leadership style to the changing environment that surrounds him, he might still be 
alive. Instead, he is power-hungry and continues to run things the way he knows best, but the club has reached a point where they are sick of his antics and progresses to a new leader, Jax.

At the beginning of Sons of Anarchy, everyone sees Jax as the rebellious vice president of SAMCRO and the one who would take Clay's position as president once that time came along. Along the way, Jax sees conflict in what Clay is doing and made it his mission to emerge as the rightful leader SACMRO needs. Jax pushes them into the right path away from the illegal activities - once the conflict between Jax and Clay grows, Jax's transformational qualities starts to blossom. Jax finds his biological father's journal that reveals how he knew Clay was going to be responsible for his demise because he wanted SAMCRO to be a legitimate motorcycle club not some outlaw group of criminals. Jax has always thought his dad was a coward thinking he killed himself, but these letters were proof that Clay was corrupt and had been deceiving the club. This also sheds light on how Clay has only kept his power and leadership position as a result of his use of deception. From the moment Jax reads those letters, he starts identifying with his father and makes his father's end goal his own. There are times where Jax thinks he may be doing more harm than good, he keeps true to his heart and the club to meet his end goal and transforms his way of doing things to make that goal happen - Unlike Clay, Jax is willing to utilize women, local law enforcement, and gangs of other ethnicities to move SAMCRO in the right direction. All three areas Jax opens up to assist SAMCRO have been barred by Clay for many years prior.

The deceptive examples chosen for this thesis were split into three categories, and each example was subcategorized as indirect and direct deception. French and Raven (1959) explain how knowledge is a vital tool for an individual in the workplace. Since SAMCRO runs their daily operations as a business, French and Raven's statement rings true to them too. The slightest 
piece of information can change SAMCRO's day in a blink of an eye. For example, when Jax and Clay make up the story that the One-Niners shot Clay at the clubhouse, Tig seeks vengeance and starts their beef with Damien Pope. The point is, those who hold the information hold power. Those people who hold power must be careful about who they tell this information to because, as seen in the show, in SAMCRO's line of work, circumstances can change within minutes.

Lunenburg (2010) explains how the leader-member exchange theory (LMX) focuses on how relationships are built between leaders and subordinates. Within Sons of Anarchy, these relationships can easily be distinguished amongst the SAMCRO members. Liden and Graen (1980) and Yukl (1981) explain that three expectations strengthen the relationships between leaders and subordinates: trust, competence, and mutual influence. These three expectations are essential for a leader to hit because subordinates are what keeps companies running. Regardless of whether the deception is direct or indirect, it can still harm those three expectations. I believe LMX depends more on the leader's style and how they carry themselves versus the type of deception at hand. If the subordinates know their leader has the correct intentions and strives to make their environment better, deception will not deter the strengths of the relationships being built - sort of like the "trust the process" motto. On the other hand, if the subordinates see their leader is selfish and overall toxic, the deception can cause a variety of issues, and those relationships will not become strong. Throughout Sons of Anarchy, Jax has been able to develop true relationships with his subordinates as a leader, whereas Clay rules everything through fear.

\section{Subordinates' Reactions to Leadership}

Deception is not just something that may assist or damage an organization, but it also has the potential to sabotage relationships between leaders and subordinates. Nahrgang, Morgeson, and Ilies (2009) discuss what it is like to have an abusive leader. The authors say that leaders 
who display abusive characteristics tend to have weaker relationships amongst their workers. They also state that these workers will interact less and not be supportive of the leader's views. The perfect example of this would be the relationship between Clay and Opie Winston. Opie has butted heads with Clay since the beginning of the show. Clay was responsible for the death of both Opie's wife Donna and father Piney - both deaths are a result of Clay's web of deception that grew larger than he could handle. As a result, Opie clashes with Clay's decisions and puts himself in near-death situations. In one instance, Opie rushes the clubhouse and fires shots into Clay's abdomen to murder him. This action shows a lack of trust, competence, and mutual influence Opie has in Clay, and he feels the need to take things into his own hands since Clay is ultimately the one who holds power. Opie does not see any change in leadership happening unless Clay is dead, and he is willing to try and murder him to see that change happen.

According to Lynne Anderrson and Christine Pearson (as cited in Thompson, Buch, \& Glasø, 2018) incivility is "a social interaction between two or more parties, where this dynamic interchange can potentially escalate into an exchange of coercive actions within an organization. As such, the negative action of one party leads to the negative reaction of the second party, increasing again to counterproductive behaviors where the obvious intent is to harm" (p.19). This interaction sums up the relationship between Clay and Piney Winston. There was a time where Piney was Clay's sponsor (one who vouches for another person to become a member of the club) into SAMCRO. Clay was responsible for the deaths of John Teller, who was Piney's best friend, and his daughter-in-law Donna. Throughout the years, their relationship started diminishing and Donna's death was the last straw for Piney and that is when the relationship they once had was no more. 
During Clay's tenure as president, he moved the club into a great deal of illegal activities. SAMCRO was never intended to be an outlaw criminal organization, but the power and greed went to Clay's head after he had a taste of what kind of profits could be made carrying out illegal business opportunities. The club has always said they would entertain these types of opportunities but would never diverge into the drug industry. As time went on, SAMCRO developed into one of the more defined criminal organizations, and the members went along with it because they also enjoyed the profits being made. But once it became more for Clay's selfgreed rather than the club, things started to turn quickly.

Clay tells Jax he is making decisions based on how he cans benefit off them because he knows his retirement is near and he needs to make enough money to sustain it. The death of Donna puts a big spike in between the relationship of Clay and Piney but agreeing to move cocaine for the cartel is the green light for Piney to make it his mission to take Clay down. Piney is sick of the way Clay is leading SAMCRO and talks with Tara Knowles (Jax's wife) and Gemma Teller (Clay's wife) about everything that is happening. He talks with Tara about the letters John Teller wrote before he died which indicates Clay is behind his murder and putting the Sons of Anarchy down a path of no return. If these letters ever went to the club, it would end Clay so Piney and Tara set-up an agreement to use the letters against Clay once the time was right. Piney then went on to tell Gemma about moving drugs for the cartel in hopes she will talk some sense into Clay about everything and to return to how he once used to be. Talking to old lady's (club members wives) about club business is a big no-no and Piney could be severely punished for doing so. This is where Piney moves from a "new lad" and is developing into a "new man" as he starts working with the woman associated with the club - he realizes the 
current status quo of SAMCRO needs to change and he is willing to adapt his ways to see this happen.

Another reaction to Clay's leadership is when Piney provides Clay with an ultimatum. After Clay finds out Piney talked with Gemma, he threatens to slit Piney's throat if he ever tries to end-run him through his old lady again. The thing is, Piney believes him. Therefore, Piney approaches Clay with an ultimatum: kill the drug-running with the cartel or SAMCRO receives the letters. This is a bold move by Piney because whenever Clay feels like his power is threatened, he spirals into a deep web of deception to the extent of no return. Piney also reveals that if Clay tries to make this all go away by killing him, he has contingencies in place for the letters to be revealed. After a few days goes by, Gemma approaches Piney about all of this and warns him Clay is going to kill him if he continues this beef. Piney knows Clay will never surrender and tarnish his ego, but he accepts that his potential death will be a marker for SAMCRO to move back in the right direction. Clay is losing his power if his subordinates are willing to go head-to-head with him over his leadership style. Instead of trying to transition into what his subordinates want to see, he continues to ignore their requests and only condone what is in his best interest. Therefore, he is continuing to lose his supporters.

After Jax frames Clay for Damien Pope's murder, Bobby Munson sits down with Jax to have a discussion. Bobby said he asked a couple of other members what went down, but nobody said a word. The silence did not stop Bobby from approaching Jax and calling him out on his actions because he knows what Jax did. Bobby told Jax he was supposed to be better than Clay and put their differences aside for the bigger picture to reach their end goal. Employees who have characteristics like Bobby, who are honest and speak their mind to their leaders, are essential to have. If all employees remain silent as the other SAMCRO members do, leaders will 
never be called out for their actions. When leaders are held accountable for their actions or called out when they do something wrong, there can be learning experiences and room for growth in the future.

Graen and Uhl-Bien (1995) explain how leaders and subordinates who have mutual trust and respect for each other beyond the employment contract forge stronger relationships. This is where change will happen because the subordinates take much pride in working for their leader; they want to be a part of that change. The authors continue to state employees with higher LMX relationships tend to do more voluntary work and excel in their daily tasks. One of the most prominent examples of a high LMX relationship in Sons of Anarchy is between Jax and Opie. When a group of SAMCRO members are locked up in prison, Jax is tasked with choosing which SAMCRO member will be killed from the order of Damian Pope (a notorious gangster out of Oakland, California). Jax confesses everything to Opie: his secrets, his aspirations for the club, and how he does not know what to do to protect everyone. As the club was ready to meet their fate and fight off their attackers, Opie suddenly attacks the head prison guard and is taken away from the rest of the group. Attacking the prison guard was Opie's way of sacrificing himself for SAMCRO because he believes in Jax's aspirations. Opie knows Jax will avenge him and transition SAMCRO into what it aspires to be. Jax is the type of leader who will never let one of his men do something like that knowingly. Opie knows that, so this was his turn to engage in deception because he understands Jax's bigger picture and wants to help him in achieving the organizational goals. Not that transactional leadership is terrible, but Opie would never have sacrificed himself for Clay as he did for Jax. Jax listens to his subordinates and tries repaving their way into a brighter future as a transformational leader. 
Another deceptive act worth highlighting from Sons of Anarchy is when Jax sleeps with another woman. When the police raids SAMCRO's clubhouse for prescription pills, it spooks Jax. It has him thinking about what can happen to Tara if she is caught - she can potentially be stripped of her medical license and put into prison. Jax could never live with himself if either of those two things happen. Therefore, he brakes things off with Tara and makes his way to the clubhouse where he decides to sleep with one of the porn stars who works for SAMCRO, Ima. The following morning Tara storms the clubhouse and walks in on Jax and Ima in the back bedroom - Jax knows she would show up that morning. He knows she would not accept his break-up the night before, so he slept with Ima to solidify that he is done with her. In reality, Jax never wanted to end things with Tara; he is still in love with her. But he knows that there is a chance she gets angry at him and takes their two sons and moves far away from him - from the illegal activity. That is what Jax truly wants. He does not want his boys to follow in the family footsteps of SAMCRO, he wants Tara to live a normal and successful life, and he knows she cannot do that by remaining with him. This is another example of how Jax displays transformational leadership. Unlike a transactional approach of doing things the same way over and over, he is altering his ways and is trying to secure a safer future for his family instead of his sons entering the "family business". Other members of the club see these types of decisions Jax makes, and although they might not agree, they are correct in the moment. Still, they see the bigger picture he is trying to accomplish, which ultimately increases their relationships amongst each other.

\section{Potential Messages to Viewers}

This television show displays a lot of deception to the extent that viewers may normalize deception. Although most people may not be working as "motorcycle mechanics" or outlaws, the 
representations of how SAMCRO is run may ring true to other industries. As stated previously, Jax portrays a more transformational leadership approach. Clay employs a more transactional leadership style - each and both leadership styles are common throughout almost every working industry. Therefore, viewers may be able to relate to some of the events that unfold on the screen. These events can be associated with Theory X and Theory Y. McGregor (1960) explains that Theory $\mathrm{X}$ leaders tend to think employees do the bare minimum work to get by, are expendable, and threaten their employees with punishment if they do not perform. Theory Y leaders care about their employees, give them an opportunity for growth, and provide the subordinates opportunities to take part in some decision making. After analyzing the deceptive examples, it is safe to say Clay exhibits Theory X while Jax displays Theory Y.

Out of the 9.2 million viewers who watched this show, it is fair to say that a large percentage probably have had some experience working for a Theory X manager or an individual who displays a transactional leadership approach. Sons of Anarchy communicates to the viewers that there is another way for things to go at the workplace - Theory Y management or transformational leadership techniques. These types of behaviors can teach subordinates that they are more than an expendable employee and can find more self-worth in another organization that takes value in their employees and their opinions for future success. Additionally, these audience members might understand why their superiors engaged in deception. Those who watch this show, who are subordinates in their workplace, may comprehend why their leaders have engaged in deceptive practices that they are aware of. Additionally, some may recognize there may be some deceptive acts their leaders have engaged in that they are not aware of. This is where trust comes into play because if subordinates cannot trust their leader there is potential for those weaker relationships to develop which can harm the organization in the long run. 
As portrayed in the television show, Clay does everything to protect his position of leadership and power even to the extent of physically harming others - it was all about the money. On the contrary, out of the audience members, there may be individuals who condone Clay's leadership style and try to mold themselves after him. There may be some individuals who have found themselves in similar situations to Clay where they had to deceive others to keep striving forward with their end goal. Additionally, those people who hold a "new lad" approach may identify with Clay's tactics and agree that his way of conducting business is the correct way and viewing these behaviors throughout the show can strengthen those beliefs because hanging onto power is one of the ultimate tools to achieve their success. Despite all the horrible events Clay has caused, he has been successful at retaining his leadership position for many years. It might not be ideal for some, but for others, it might be just enough.

Peterson (2007) explains that it is practical for leaders to be flexible and develop trust with their subordinates. As the show progresses, that is precisely what Jax does. Jax starts adjusting to new ways of doing things and gains the respect and loyalty of all his fellow brothers throughout his journey to push SAMCRO into their end goal. Thomas and Bostrom (2008); Rodrigues (2007); \& Sager (2008) all discuss how Theory X qualities are still essential to have as a business leader, but it is an outdated style so today's leaders must be able to adjust their methods accordingly to achieve overall success for the business. Audience viewers can see that Jax has done this and that his style of deception is for the better good. This can show that not all deception is terrible, and it depends on the individual who is utilizing it.

Furthermore, after watching this show, individuals may want to work for a transformational leader because they value their employees and provide opportunities for growth. This environment may boost morale and worker productivity, which will help achieve the 
organization's end goal. In retrospect, Sons of Anarchy has shown viewers that leadership is a game of deception. Regardless of which type of leadership style an individual exhibits, there are goals to be met and money to be made - one of the most effective tools a leader can use to achieve those is the utilization of deception.

\section{Conclusion}

This chapter has analyzed numerous examples of deception that are depicted in the television show Sons of Anarchy. This show had a large amount of deception throughout the entire series. This thesis does not include all the deceptive moments captured in the show but includes the ones that relate to leadership and deception. Each deceptive example included in this analysis was categorized into one of the three motives: For one's self-gain, for the benefit of the club, and for both one's self-gain and the benefit of the club - Furthermore, each deceptive example was categorized as direct or indirect. Additionally, this chapter discussed the messages found in the deceptive acts. As previously stated, the Sons of Anarchy is not a traditionally run business, but it functions as one. Therefore, watching the club members' interactions throughout the seven seasons has shed light on the relationship between leadership and deception.

Deception is a tactic which leaders use frequently to reach the end goals of either themselves or the organization they are a part of. Those who watched this show may conclude that the large amount of deception is a result from the illegal activities the club encounters on a daily basis. In the next chapter I will discuss directions for future researchers to take while looking at deception in the workplace. 


\section{CHAPTER V: DISCUSSION}

In the previous chapter, various examples of deception between leaders and subordinates were analyzed, which had motives for one's self-gain, the benefit of the club, and both self-gain and the benefit of the club. Additionally, I looked at the messages those deceptive examples displayed. In this chapter, I will discuss implications to this study, relationships in the workplace, and possibilities of future research into how deception is used as a leadership tactic throughout the television show.

My tenure at Jersey Mike's sparked the idea for this entire thesis. Chapter one was an overview of what was to come throughout this thesis. Chapter two was a literature review that went over the vast amount of content seen in this document. Leadership, deception, power, and previous media studies were discussed in detail to provide readers with a better understanding of these concepts. Chapter three contains a synopsis of the television show Sons of Anarchy, the explanation of methods used for this thesis, and a description of the theoretical framework for this study. Lastly, chapter four laid out the various story arcs, and deceptive acts analyzed in this thesis and there was a discussion of the messages displayed from those deceptive acts.

Something that makes this study unique is the business being studied. The Sons of Anarchy are an outlaw motorcycle gang. Usually, deception and leadership studies tend to focus on more traditional, white-collar organizations. Instead of going the conventional route, I decided to study a gang because it functions very similarly to a traditional business. Like a professional organization, a gang has a hierarchal structure, organizational goals, culture, rules, and such. I want to note that not everyone in the world - or even all of the viewers of this television show - has the privilege to attend college or receive the proper training needed to 
obtain these white-collar positions. Therefore, joining a gang might be seen as the "traditional" job for many people throughout the world.

\section{Directions for Future Research}

Despite the amount of research and efforts put into this thesis, there are additional directions that scholars can take if they wish to continue examining how leaders utilize deception in the television show Sons of Anarchy. The first direction for future researchers would be to discuss the show with the audience. The final season finale brought in approximately 9.2 million viewers - this means there was a massive audience for this show who witnessed all the deceptive examples examined in this thesis. If I decided to discuss these examples with the audience, I could find out how they interpreted the deception.

Even though SAMCRO is a motorcycle gang, they still operate like a traditional business. There is a boss who holds power, there are subordinates who carry out tasks, there are organizational goals that need to be met throughout the series, and they have competitors like any other business would have. Discussing how audiences perceive their own work experiences through the lens of Sons of Anarchy would be an essential step for future researchers because there could be a portion of the audience who thinks some of the deceptions they saw is how their own business should be operated.

This thesis only focused on the television show Sons of Anarchy, where leadership and deception are apparent throughout the entire series. If future scholars wanted to examine the relationship between leadership and deception further, they must incorporate additional television shows or movies that display these factors. This would provide further insight into how other groups or organizations utilize deception in their operations. Additionally, the findings in the other programs could be compared to the findings in this thesis. The researchers can 
provide a more in-depth insight to see if the patterns found in this thesis ring true to other types of organizations where deception occurs. It would be interesting to see if more traditional businesses, like in the show Mad Men, have leaders who portray the same type of leadership styles and engage in deception for the same reasonings as to the ones in Sons of Anarchy.

\section{Story Arc Limitations}

The last piece of direction that can be offered to future researchers would be to analyze every story arc that portrayed deception in Sons of Anarchy. I only focused on the main arcs that involved deception that could somehow be connected to the two leaders within the show, Clay and Jax. There was a lot of deception throughout the show from characters who were not in leadership positions. If researchers decided to include the deception from these perspectives, it could explain why people who do not hold a position of leadership or power engage in deception.

Furthermore, I decided to leave out a story arc involving Jax working with and against the Chinese gang. There were times within the arc where the deception was getting overlapped by further deception, and things were becoming hard to follow. The actions for engaging in deception continued going back and forth, and it would have been difficult to justify why the club continued acting in this way. There were also many parties involved in this story arc that SAMCRO kept being deceitful to, and there were also times where the other parties were engaging in deception against the club. If further researchers took the time to break down everything within this story arc, it could help provide a more profound sense of why Jax engages in deception. 


\section{Discussion of Direct Deception Versus Indirect Deception}

As seen in chapter four, each deceptive theme was categorized into sub-themes: direct deception and indirect deception. Direct deception is when an individual tells a lie of commission. For example, Clay Morrow tells Opie Winston they are good - this is a lie of commission. Indirect deception is when an individual tells a lie of omission. For example, even though Clay tells Opie they are good, Clay does not say that Tig Trager is searching his truck and personal belongings for any evidence that he is a rat.

I noticed direct deception mainly dealt with face to face communication between either party being deceived. In comparison, indirect deception tends to have some element of deceiving someone behind their back. This is a new pattern of studying deception and assists in the comprehension of interpersonal deception theory. I encourage future researchers to try and analyze deception in this manner.

\section{Discussion of Relationships in the Workplace}

One thing I discovered in completing this thesis is that there is a lack of studies on the interpersonal relationships portrayed in Sons of Anarchy. Something to note, SAMCRO has multiple members related to each other, and for those not related by blood, they have been connected to the club for quite some time. There were father and son relationships, stepfather and stepson relationships, mother and son relationships, best friend relationships, and romantic relationships within SAMCRO throughout all seven seasons. Keep in mind, their motorcycle gang is supposed to be run like an operating business. In media, this scenario makes for great drama, but what if this was a reality for some? Workplace relationships are supposed to remain at a professional level, as colleagues. This is where things start to get tricky because can Clay and Jax be stepfather and stepson when they are the heads of a major outlaw organization? It is 
vital to keep your work life, and personal life separated. As viewers see throughout the series, their personal and professional lives became intertwined and became the demise of whatever piece of relationship they had left. This would be an exciting factor to see studies in future studies. Studying how personal and professional relationships interact within the workplace will provide a better insight on if success is hindered or remains unchanged based on the relationship.

Another implication related to relationships is not using Gemma Teller as one of the main characters of focus while studying deception. Gemma is arguably the real leader of SAMCRO, as she is the mother of Jax and wife of Clay. She may serve as an old lady, but she is the most deceptive person within the television show. Whatever Gemma wants, she tends to get due to her skills at employing deception. I decided not to add her to this study because it would have added too many elements, such as gender differences and a more significant focus on family communication. I wanted to focus this research on leaders within an organization, and since old ladies are not technically members of the club, I decided to leave her out. If future researchers wanted to continue this type of study with Sons of Anarchy, I encourage them to investigate Gemma's character and compare it to Jax and Clay's.

\section{Discussion of Transformational and Transactional Leadership}

Throughout the series, Jax and Clay served as the leaders of SAMCRO. Despite being powerful and effective in their ways, they both employed a different leadership approach. Jax displayed a more transformational leadership style where he cares about the fut ure of the organization, values his employees and their feedback, and is open to adapting the business to the changing times. In comparison to Clay, who leads with a transactional approach by making sure tasks were done his way, saw his subordinates as expendable, and did not care about the 
future of the organization. He wanted to make sure everything was right at the moment and cared about making a quick profit.

As a result of this thesis, it was determined that Sons of Anarchy displayed transactional leadership as the type of leadership that frequently employed deception. On the other hand, the show portrayed transformational leadership as the type of leadership that utilizes deception most effectively. Something also noticed while conducting this study was that the transactional leader (Clay) often used deception to benefit himself. In comparison to the transformational leader (Jax), who engaged in lots of deception for both himself but also the club. If viewers were polled after watching this series to see which type of leader they would want to work under, I'm assuming it would fall under someone such as Jax. Jax made mistakes throughout his time as a leader, but he still treats his fellow club members like family and does everything to make sure they succeed. Those are traits a quality leader must possess to have the obedience of subordinates.

As mentioned earlier, this television show depicts a non-traditional workplace in a fictional setting. I encourage future researchers to study deception and leadership in the workplace out in the real world. It would be fascinating to see if the results from Sons of Anarchy ring true to real-world organizations. I further suggest that if this study was to be conducted in actual work environments, researchers should investigate all different types of work industries: gangs, corporate organizations, the fast food and retail industry, and the trades industry. Comparing the findings across the working sectors will bring a much deeper insight into the deceptive comparison and effectiveness between the transformational leadership and transactional leadership approach - it might also shed light on which method sustains a lower turnover rate amongst subordinates. This thesis focused on the story arcs in the show itself. 
Future researchers could go a step further and study the viewers to see what messages about deception and leadership they are taking and incorporating into their own lives as a result of watching this show.

\section{Conclusion}

This chapter discussed advice for future research if future scholars wanted to take this topic a step further. Organizations must know what their overall objectives are and more importantly how they want to achieve those goals. Leaders must be chosen carefully because the approaches they employ can make all the difference in how that organization functions. This thesis has highlighted it is imperative those in a position of power understand how to connect with their subordinates and make decisions for the overall benefit of the organization. If those in a position of power are able to adapt their leadership skills effectively, it will make all the difference for the organization to sustain itself in this rapidly changing world.

This thesis has shown that when one holds a leadership position, there are obstacles that come along with it. Leaders must retain their power and protect it by all means necessary to continue their journey. As Jax notes in Sons of Anarchy, "I feel like my life has taken a turn. I'm heading down a road I've never been on before. Nothing is familiar. The signs don't make sense. Do I get off the road, or do I keep riding? The people that I see aren't the people I know. Do I go alone or take others with me? Who do I trust, and who do I not? I now understand why being a leader requires isolation" (Sutter \& Barclay, 2013). 


\section{REFERENCES}

Andersson, L., \& Pearson, C. (1999). Tit for tat? The spiraling effect of incivility in the workplace. Academy of Management Review, 24(3), 452-471. doi: 10.2307/259136

Bass, B. M. (1985). Leadership and performance: Beyond expectations. New York, NY: Free Press.

Bass, B. M. (1990). From transactional to transformationalleadership: Learning to share the vision. Organizational Dynamics, 18(3), 19-31. doi: 10.1016/0090-2616(90)90061-s

Bassett, J. F. (2014). Every day is a box for the reaper crew: The quest for death transcendence and conflicting moral virtues in Sons of Anarchy? PsyArt, 18, 249-265.

Braun, V., \& Clarke, V. (2006). Using thematic analysis in psychology. Qualitative Research in Psychology, 3(2), 77-101. doi: 10.1191/1478088706qp063oa

Buller, D. B., \& Burgoon, J. K. (1996). Interpersonal deception theory. Communication Theory, 6(3), 203-242. doi: 10.1111/j.1468-2885.1996.tb00127.x

Clipa, O., \& Greciuc, Ş. M.-A. (2018). Relations of style of leadership and achievement motivation for teacher. Romanian Journal for Multidimensional Education / Revista Romaneasca Pentru Educatie Multidimensionala, 10(4), 55-64. doi: 10.18662/rrem/72

Collins, C. \& Bush, J. (Writers), \& Kay, S. T. (Director). (2010). The Push [Television series episode]. In K. Sutter (Producer), Sons of Anarchy. North Hollywood, California: Occidental Studios.

Collins, C. \& Sutter, K. (Writers), \& Sutter, K. (Director). (2012). J'ai Obtenu Cette [Television series episode]. In K. Sutter (Producer), Sons of Anarchy. North Hollywood, California: Occidental Studios. 
Collins, C. \& Sutter, K. (Writers), \& Weller, P. (Director). (2012). Darthy [Television series episode]. In K. Sutter (Producer), Sons of Anarchy. North Hollywood, California: Occidental Studios.

Conrad, B. (Writer), \& Gierhart, B. (Director). (2008). Hell Followed [Television series episode]. In K. Sutter (Producer), Sons of Anarchy. North Hollywood, California: Occidental Studios.

Corrado, R. \& Ramirez, M. (Writers), \& Gierhart, B. (Director). (2011). Kiss [Television series episode]. In K. Sutter (Producer), Sons of Anarchy. North Hollywood, California: Occidental Studios.

Corrado, R. \& Sagal, L. (Writers), \& Weller, P. (Director). (2011). Dorylus [Television series episode]. In K. Sutter (Producer). Sons of Anarchy. North Hollywood, California: Occidental Studios.

Cox, N. B., \& DeCarvalho, L. J. (2016). "Ride free or die" trying: Hypermasculinity on FX's Sons of Anarchy. The Journal of Popular Culture, 49(4), 818-838. doi: $10.1111 /$ jpcu. 12438

Daniels, M., Barcheski, J., \& Sutter, K. (Writers), \& Barclay, P. (Director). (2012). To Thine Own Self [Television series episode]. In K. Sutter (Producer), Sons of Anarchy. North Hollywood, California: Occidental Studios.

Densley, J. A. (2012). The organisation of London's street gangs. Global Crime, 13(1), 42-64. doi: $10.1080 / 17440572.2011 .632497$

Depaulo, B. M., Lindsay, J. J., Malone, B. E., Muhlenbruck, L., Charlton, K., \& Cooper, H. (2003). Cues to deception. Psychological Bulletin, 129(1), 74-118. doi: 10.1037/00332909.129.1.74 
Driskell, J. E., Salas, E., \& Driskell, T. (2012). Social indicators of deception. Human Factors: The Journal of the Human Factors and Ergonomics Society, 54(4), 577-588. doi: $10.1177 / 0018720812446338$

DuBrin, A. J. (2009). Political behavior in organizations. Thousand Oaks, CA: Sage Dunbar, N. E., Jensen, M. L., Bessarabova, E., Burgoon, J. K., Bernard, D. R., Harrison, K. J.,...

Eckstein, J. M. (2012). Empowered by persuasive deception. Communication Research, 41(6), 852-876. doi: 10.1177/0093650212447099

Ekman, P., \& Friesen, W. V. (1969). Nonverbal leakage and clues to deception. Psychiatry, 32(1), 88-106. doi: 10.1080/00332747.1969.11023575

Ekman, P., Friesen, W. V., \& Simons, R. C. (1985). Is the startle reaction an emotion? Journal of Personality and Social Psychology, 49(5), 1416- 1426. doi: 10.1037/00223514.49.5.1416

Ekman, P. (1992). Telling lies. New York: Norton. (Original work published 1985)

Erickson, A., Shaw, B., Murray, J., \& Branch, S. (2015). Destructive leadership: Causes, consequences and countermeasures. Organizational Dynamics, 44, 266-272. doi: 10.1016/j.orgdyn.2015.09.003

Erickson, D., Sagal, L., \& Sutter, K. (Writers), \& Ferland, G. (Director). (2010). Lochan Mor [Television series episode]. In K. Sutter (Producer), Sons of Anarchy. North Hollywood, California: Occidental Studios.

Erickson, D. \& Collins, C. (Writers), \& Ferland, G. (Director). (2011). Booster [Television series episode]. In K. Sutter (Producer). Sons of Anarchy. North Hollywood, California: Occidental Studios. 
Erickson, D. \& Long, S. (Writers), \& Barclay, P. (Director). (2009). Balm [Television series episode]. In K. Sutter (Producer). Sons of Anarchy. North Hollywood, California: Occidental Studios.

Erickson, D. \& Dahl, B. (Writers), \& Barclay P. (Director). (2011). Brick [Television series episode]. In K. Sutter (Producer). Sons of Anarchy. North Hollywood, California: Occidental Studios.

Erickson, D. \& Dahl, B. (Writers), \& Maibaum, P. (Director). (2011). Family Recipe [Television series episode]. In K. Sutter (Producer). Sons of Anarchy. North Hollywood, California: Occidental Studios.

French, J. R. P., \& Raven, B. (1959). The bases of social power. In D. Cartwright (Ed.), Studies of social power (pp. 150-167). Ann Arbor, MI: University of Michigan, Institute for Social Research

Gerstner, C. R., \& Day, D. V. (1997). Meta-analytic review of leader-member exchange theory: Correlates and construct ideas. Journal of Applied Psychology, 82(6), 827-844. doi: $10.1037 / 0021-9010.82 .6 .827$

Gibson, J. L, Ivancevich, J. M., Donnelly, J. H., \& Konopaske, R. (2012). Organizations: Behavior, structure, processes (14th ed.). New York, NY: McGraw-Hill Irwin

Graen, G. B., \& Uhl-Bien, M. (1995). Relationship-based approach to leadership: Development of leader-member exchange (LMX) theory of leadership over 25 years: Applying a multilevel multi-domain perspective. The Leadership Quarterly, 6(2), 219-247. doi: $10.1016 / 1048-9843(95) 90036-5$

Johnson, C. T. (2019). The art of asking a question an adaptation tool for rapport-base elicitation and interrogation. Polygraph, 52(4), 77-79. 
Kabeyi, M. J. B. (2018). Transformational vs transactional leadership with examples. The International Journal of Business \& Management, 6(5), 191-193.

Kennedy, L. W., \& Baron, S. W. (1993). Routine activities and subculture of violence: A study of violence on the street. Journal of Research in Crime and Delinquency, 30(1), 88-112. doi: $10.1177 / 0022427893030001006$

Khajeh, E. H. (2018). Impact of leadership styles on organizational performance. Journal of Human Resources Management Research, 2-10. doi: 10.5171/2018.687849

Koerner, A. F., Schrodt, P., \& Fitzpatrick, M. A. (2005). Family communication patterns theory. In D. Braithwaite, E. Sutter, \& K. Floyd (Eds.), Engaging Theories in Family Communication (pp. 142-153). Thousand Oaks, CA: Sage Publications

Law, L. (2017). Everybody lies: A discourse analysis of deceptions in TV drama House M.D. The Hong Kong Polytechnic University, 1-38. doi: 10.13140/RG.2.2.26802.40644

Lee, K. L., \& Low, G. T. (2008). Bases of power and subordinates' satisfaction with supervision - The contingent effect of educational orientation. International Education Studies, 1(2), 3-13. doi: 10.5539/ies.v1n2p3

Leverso, J., \& Matsueda, R. L. (2019). Gang organization and gang identity: An investigation of enduring gang membership. Journal of Quantitative Criminology, 35(4), 797-829. doi: 10.1007/s10940-019-09408-X

Levine, T. R. (2014). Truth-default theory (TDT): A theory of human deception and deception detection. Journal of Language and Social Psychology, 33(4) 378-392. doi: $10.1177 / 0261927 X 14535916$

Lewicki, R. J., \& Robinson, R. J. (1998). Ethical and unethical bargaining tactics: An empirical study. Journal of Business Ethics, 17(6), 665-882. doi:10.1023/A:1005719122519 
Liden, R. C., \& Graen, G. (1980). Generalizability of the vertical dyad linkage model of leadership. Academy of Management Journal, 23(3), 451-465. doi: 10.2307/255511

Lindsey, L. L. M., Dunbar, N. E., \& Russell, J. (2011). Deception and power in the workplace. Journal of Organizational Culture, Communications and Conflict, 15(1), 55-79. Retrieved from: http://hdl.handle.net/10945/56702

Littleton, C. (2014, December 15). 'Sons of Anarchy' Finale Rides Off with 9.2 Million Viewers. Variety. Retrieved from https://variety.com/2014/tv/news/sons-of-anarchy-finale-ridesoff-with-9-2-million-viewers-1201380072/.

Lunenburg, F. C. (2010). Leader-member exchange theory: Another perspective on the leadership process. International Journal of Management, Business, and Administration, 13(1), 1-5.

Lunenburg, F. C. (2012). Power and leadership: An influence process. International Journal of Management, Business, and Administration, 15(1), 1-9.

Mazur, M. A., \& Kalbfleisch, P. J. (2003). Lying and deception detection in television families. Communication Research Reports, 20(3), 200-207. doi: 10.1080/08824090309388818

McDonald, G. W. (1980). Family power: The assessment of a decade of theory and research, 1970-1979. Journal of Marriage and the Family, 42(4), 841-854.

McGregor, D. (1960). The human side of enterprise. New York City, N.Y.: McGraw Hill

Meijer, E. H., \& Verschuere, B. (2010). The polygraph and the detection of deception. Journal of Forensic Psychology Practice, 10(4), 325-338. doi: 10.1080/15228932.2010.481237 
Nahrgang, J. D., Morgeson, F. P., \& Ilies, R. (2009). The development of leadermemberexchanges: Exploring how personality and performance influence leader and member relationships over time. Organizational Behavior and Human Decision Processes, 108(2), 256-266. doi: 10.1016/j.obhdp.2008.09.002

Nanjundeswaraswamy, T. S., \& Swamy, D. R. (2014). Leadership styles. Advances Management, 7(2), 57-62.

National Research Council. (2003). The polygraph and lie detection. Washington, DC: National Academies Press.

Navarro, J. (2003). A four-domain model for detecting deception: An alternative paradigm for interviewing. FBI Law Enforcement Bulletin, 72(6), 19-24. doi: 10.1037/e312592004005

Newman, M. Z. (2006). From beats to arcs: Toward a poetics of television narrative. The Velvet Light Trap, 58(1), 16-28. doi: 10.1353/vlt.2006.0033

Nijjar, J. K. (2018). Mutated masculinities: A critical discourse analysis of the new lad and the new man in Sons of Anarchy and Ray Donovan. The Journal of Men's Studies, 27(1), 24-44. doi: 10.1177/1060826518782196

Nunn, K., Sagal, L., \& Sutter, K. (Writers), \& Arkin, A. (Director). (2012). Laying Pipe [Television series episode]. In K. Sutter (Producer), Sons of Anarchy. North Hollywood, California: Occidental Studios

Odumeru, J. A., \& Ogbonna, I. G. (2013). Transformational vs. transactional leadership theories: Evidence in literature. International Review of Management and Business Research, 2(2), $355-361$. 
Ofen, N., Whitfield-Gabrieli, S., Chai, X. J., Schwarzlose, R. F., \& Gabrieli, J. D. E. (2016). Neural correlates of deception: lying about past events and personal beliefs. Social Cognitive and Affective Neuroscience, 12(1), 116-127. doi: 10.1093/scan/nsw151

Payne, H. J. (2008). Targets, strategies, and topics of deception among part-time workers. Employee Relations, 30(3), 251-263. doi: 10.1108/01425450810866523

Peterson, T. M. (2007). Motivation: How to increase project team performance. Project Management Journal, 38(4), 823-83. doi: 10.1002/pmj.20019

Pienaar, C. (2009). The role of self-deception in leadership ineffectiveness - a theoretical overview. South African Journal of Psychology, 39(1), 133-141. doi: $10.1177 / 008124630903900112$

Plunkett, W. R. (1996). Supervision: Diversity and teams in the workplace. Upper Saddle River, N.J.: Prentice-Hall.

Polic, I. (2019). Leadership styles determine proactivity of employees - A vessel's example. Annals of Maritime Studies, 56(1), 39-58.

Porter, M. J., Larson, D. L., Harthcock, A., \& Nellis, K. B. (2002). Re(de)fining narrative events examining television narrative structure. Journal of Popular Film and Television, 30(1), 23-30. doi: 10.1080/01956050209605556.

Prince, R. (2011). Bodyguard of lies: The vicissitudes of deception among mad men and women. The American Journal of Psychoanalysis, 71(4), 376-380. doi: 10.1057/ajp.2011.31

Raven, B. H. (1965). Social influence and power. In I. D. Steiner \& M. Fishbein (Eds.), Current studies in social psychology (pp. 371-381). New York, N.Y.: Holt, Rinehart \& Winston. 
Raven, B. H. (2008). The bases of power and the power/interaction model of interpersonal influence. Analyses of Social Issues and Public Policy, 8(1), 1-22. doi: 10.1111/j.15302415.2008.00159.x

Robbins, S. P., \& Judge, T. A. (2011). Organizational behavior (14th ed.). Upper Saddle River, NJ: Pearson

Rodrigues, C. A. (2007). The quality organization: A conceptual framework. Total Quality Management, 18(7), 697-713. doi: 10.1080/14783360701349658

Ruble, N. M., \& Turner, W. L. (2000). A systemic analysis of the dynamics and organization of urban street gangs. The American Journal of Family Therapy, 28(2), 117-132. doi: $10.1080 / 019261800261707$

Sagal, L. \& Rodriguez, G. (Writers), \& Horder-Payton, G. (Director). (2011). Call of Duty [Television series episode]. In K. Sutter (Producer), Sons of Anarchy. North Hollywood, California: Occidental Studios.

Sagal, L. \& Sutter, K. (Writers), \& Gierhart, B. (Director). (2012). Andare Pescare [Television series episode]. In K. Sutter (Producer), Sons of Anarchy. North Hollywood, California: Occidental Studios.

Sanders, W. B. (1994). Gangbangs and drive-bys: Grounded culture and juvenile gang violence. New York, N.Y.: Aldine De Gruyter.

Sanger, K. L. (2008). An exploratory study of the relationships between theory X/Y assumptions and superior communicator style. Management Communication Quarterly, 22(2), 288312. doi: $10.1177 / 0893318908323148$

Saxe, L. (1991). Lying: Thoughts of an applied social psychologist. American Psychologist, 46(4), 409-415. doi: 10.1037/0003-066x.46.4.409 
Şirin, Y. E., Aydın, Ö. P., \& Bilir, F. (2018). Transformational-transactional leadership and organizational cynicism perception: Physical education and sport teachers sample. Universal Journal of Educational Research, 6(9), 2008-2018. doi:

10.13189/ujer.2018.060920

Sungu, L. J., Weng, Q., \& Xu, X. (2019). Organizational commitment and job performance: Examining the moderating roles of occupational commitment and transformational leadership. International Journal of Selection and Assessment, 27(3), 280-290. doi: 10.1111/ijsa.12256

Sutter, K. (Writer), \& O’hara, T. (Director). (2008). The Sleep of Babies [Television series episode]. In K. Sutter (Producer), Sons of Anarchy. North Hollywood, California: Occidental Studios.

Sutter, K. (Writer), \& Barclay, P. (Director). (2012). Sovereign [Television series episode]. In K. Sutter (Producer), Sons of Anarchy. North Hollywood, California: Occidental Studios.

Sutter, K. (Writer), \& Barclay, P. (Director). (2013). Straw [Television series episode]. In K. Sutter (Producer), Sons of Anarchy. North Hollywood, California: Occidental

Sutter, K. \& Erickson, D. (Writers), \& Kay, S. T. (Director). (2008). Capybara [Television series episode]. In K. Sutter (Producer), Sons of Anarchy. North Hollywood, California: Occidental Studios.

Sutter, K. \& Ramirez, M. (Writers), \& Gierhart, B. (Director). (2011). Una Venta [Television series episode]. In K. Sutter (Producer), Sons of Anarchy. North Hollywood, California: Occidental Studios. 
Sutter, K. \& Erickson, D. (Writers), \& Barclay, P. (Director). (2011). Burnt and Purged Away [Television series episode]. In K. Sutter (Producer), Sons of Anarchy. North Hollywood, California: Occidental Studios.

Thrasher, F., M. (1927). The Gang: A study of 1,313 gangs in Chicago. Chicago, IL: University of Chicago Press.

Thomas, D. \& Bostrom, R. (2008). Building trust and cooperation through technology adaption in virtual teams: Empirical field evidence, Information Systems Management, 25(1), 45 56. doi:10.1080/10580530701777149

Thompson, G., Buch, R., \& Glasø, L. (2018). Low-quality LMX relationships, leader incivility, and follower responses. Journal of General Management, 44(1), 17-26. doi:10.1177/0306307018788808

Tita, G. E. (1999). An ecological study of violent urban street gangs and their crime. (Doctoral dissertation Carnegie Mellon University).

Unaeze, F. E. (2003). Leadership or management. The Reference Librarian, 39(81), 105-117. doi: 10.1300/j120v39n81_09

Vecchio, R. P. (1997). Are you in or out with your boss? In R. P. Vecchio (Ed.), Leadership: Understanding the dynamics of power and influence in organizations (pp. 274-277). Notre Dame, IN: University of Notre Dame Press.

Vigil, J. (1996). Street baptism: Chicano gang initiation. Human Organization, 55(2), 149-153. doi: 10.17730/humo.55.2.3358547x86552mg4

Wang, G., Chen, H., \& Atabakhsh, H. (2004). Criminal identity deception and deception detection in law enforcement. Group Decision and Negotiation, 13(2), 111-127. doi: 10.1023/b:grup.0000021838.66662.0c 
Wayne, M. L. (2014). Mitigating colorblind racism in the postnetwork era: Class-inflected masculinities in The Shield, Sons of Anarchy, and Justified. The Communication Review, 17(3), 183-201. doi: 10.1080/10714421.2014.930271

Winston, B. E., \& Patterson, K. (2006). An integrative definition of leadership. International Journal of Leadership Studies, 1(2), 6-66.

Wood, E. A. (2016). Hypermasculinity as a scenario of power. International Feminist Journal of Politics, 18(3), 329-350. doi: 10.1080/14616742.2015.1125649

Xu, C., \& Schriesheim, C. A. (2018). Deceptive influence in the workplace. Academy of Management Proceedings, 2018(1), 14976. doi: 10.5465/ambpp.2018.159

Yukl, G. (1981). Leadership in organizations. Englewood Cliffs, NJ: Prentice Hall.

Zeinab, N. B., Khorasan, H. M., \& Eskandani, F. A. (2019). Investigating the effect of transformational leadership on employees' communicational performance. Revista Orbis, $14(42), 40-52$.

Zuckerman, M., DePaulo, B. M., \& Rosenthal, R. (1981). Verbal and non-verbal communication of deception. In L. Berkowitz (Ed.), Advances in experimental and social psychology (pp. 1-59). New York, NY: Academic Press. 